


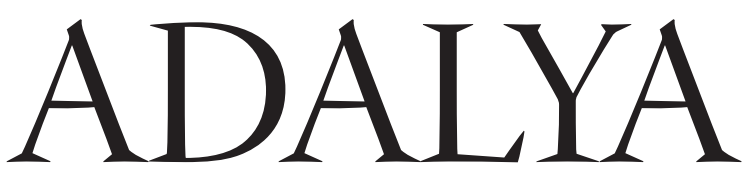

The Annual of the Koç University Suna \& İnan Kıraç Research Center for Mediterranean Civilizations

(OFFPRINT) 


\section{ADALYA}

The Annual of the Koç University Suna \& İnan Kıraç Research Center for Mediterranean Civilizations (AKMED)

Mode of publication

Adalya, a peer reviewed publication, is indexed in the A\&HCI

(Arts \& Humanities Citation Index) and CC/A\&H (Current Contents / Arts \& Humanities)

Adalya is also indexed in the Social Sciences and Humanities Database of TÜBİTAK/ULAKBIM TR index and EBSCO.

Publisher certificate number

Worldwide periodical

18318

ISSN 1301-2746

Publisher management

Koç University

Rumelifeneri Yolu, 34450 Sariyer / İstanbul

Publisher Umran Savaș İnan, President, on behalf of Koç University

Editor-in-chief Oğuz Tekin

Editors Tarkan Kahya and Arif Yacı

English copyediting Mark Wilson

Editorial Advisory Board (Members serve for a period of five years)

Prof. Dr. Mustafa Adak, Akdeniz University (2018-2022)

Prof. Dr. Engin Akyürek, Koç University (2018-2022)

Prof. Dr. Nicholas D. Cahill, University of Wisconsin-Madison (2018-2022)

Prof. Dr. Edhem Eldem, Boğaziçi University / Collège de France (2018-2022)

Prof. Dr. Mehmet Özdoğan, Emeritus, Istanbul University (2016-2020)

Prof. Dr. C. Brian Rose, University of Pennsylvania (2018-2022)

Prof. Dr. Charlotte Roueché, Emerita, King's College London (2019-2023)

Prof. Dr. Christof Schuler, DAI München (2017-2021)

Prof. Dr. R. R. R. Smith, University of Oxford (2016-2020)

(c) Koç University AKMED, 2020

Production Zero Production Ltd.

Abdullah Sok. No. 17 Taksim 34433 İstanbul

Tel: +90 (212) 2447521 • Fax: +90 (212) 2443209

info@zerobooksonline.com; www.zerobooksonline.com

Printing Fotokitap Fotoğraf Ürünleri Paz. ve Tic. Ltd. Şti.

Oruç Reis Mah. Tekstilkent B-5 Blok No: 10-AH111

Esenler - İstanbul / Turkey

Certificate number: 47448

Mailing address

Barbaros Mah. Kocatepe Sok. No. 22

Kaleiçi 07100 Antalya - TURKEY

Tel: +90 (242) 24342 74 • Fax: +90 (242) 2438013

https://akmed.ku.edu.tr

E-mail address $\quad$ adalya@ku.edu.tr 


\section{Contents}

Burçin Erdoğu

Capturing the Seen and Unseen in the Beldibi Rock Art .. 1

Özlem Çevik - Murat Dirican - Aydın Ulubey - Osman Vuruşkan

The Galena Objects from Neolithic Ulucak: The Earliest Metallic Finds in Western Turkey 7

Abdullah Hacar - K. Aslıhan Yener

Anatolian Pot Marks in the 3rd Millennium BC: Signage, Early State Formation, and

Organization of Production 25

A. Tuba Ökse

Reflection on the Sunrise Positions in Early and Middle Bronze Age Extramural

Cemeteries in Anatolia 59

Sevgül Çilingir Cesur

The Timing of Ritual Performance in Hittite Texts: The "Morning" Rites 87

Dries Daems

Reassessing the Origin of Polis in Lycia and Southwest Anatolia 111

Fatma Şahin - Erkan Alkaç

Banded Bowls from Tepebağ Höyük (Cilicia Pedias)

Özgün Kasar - Kaan İren

Leaded Bronze Arrowheads at Daskyleion 175

Hazar Kaba

An Elite Tomb from Soloi: New Evidence for the Funerary Archaeology of Cyprus

Erkan Alkaç - Ulus Tepebaş

The Gem Stamp on the Handle of a Mushroom-rimmed Amphora from Knidos:

An Assessment of the Centauromachy in Terms of Stamps and Iconography

Hüseyin Sami Öztürk - Ögül Emre Öncü

Olympos in Lycia: A Novel Assessment of its History and Localization in Light of Recent

Archaeological and Epigraphical Research

Nihal Tüner Önen

Two New Inscriptions from the Claudian Period at Perge 277

Handegül Canlı

A Unique Roman Folding Knife Handle with Eagle Ornament from Philadelphia in Cilicia 289 
Şenkal Kileci - Birol Can

A New Honorific Inscription from Blaundos: Tiberius Claudius Lucius, the Priest of

Dionysos Kathegemon

Ahmet Tolga Tek - Hacer Sancaktar

A Numismatic Riddle from Arykanda: The God of the Water Spring .

Mark Wilson

The Discovery of a Menorah in Attalia (Kaleiçi, Antalya) and its Significance for

Jewish Communities in Pamphylia

Özgü Çömezoğlu Uzbek

A North African Plate Unearthed in the Andriake Excavations

Philip Bes

Early Byzantine Pottery from Limyra's West and East Gate Excavations

Nilgün Elam

Ecclesiastical Personages of Side ( $\Sigma i \delta \eta$ ) of Pamphylia according to Literary and Sphragistic Data

Ömür Bakırer

Window Glass from the Excavations in the Seljuk Palace at Alanya

Mahmut Demir - Terrance Michael Patrick Duggan - Erkan Kurul

Observations and Assessments of Some Epigraphic Graffiti Found on Entrances in

Kaleiçi/Antalya

Ayşe Ozil

A Traveller in One's Homeland: Local Interest in Archaeology and Travel Writing in the

Ottoman Greek World in 19th Century Anatolia

Alex Rodriguez Suarez

Two Church Bells from Antalya: Traces of the Religious Soundscape of the Late Ottoman Period 517 


\title{
A Numismatic Riddle from Arykanda: The God of the Water Spring
}

\author{
AHMET TOLGA TEK - HACER SANCAKTAR*
}

\author{
Dedicated to the loving memory of Prof. Cevdet Bayburtluoğlu who first \\ excavated Arykanda and was a mentor and inspiration to many young students \\ who worked there with him, including the present authors.
}

\begin{abstract}
Among the coin types minted for Arykanda under Emperor Gordianus III, there is a new reverse type depicting Kakasbos wearing military attire and a Thracian helmet. His club is lowered, and he is holding the reins of his horse which stands next to him. On Kakasbos's right the horse with its right front hoof is striking a rock from which water flows. The iconography is new for Kakasbos and has never been seen before. In fact, he is always shown riding his horse with his club raised to strike. This article explains why this is an image of Kakasbos and not some other deity. It uses other archaeological finds - epigraphic and iconographic - found during the excavations at Arykanda. The authors also identify the water source meant on the coin type and the cult area that existed next to it at Suyun Gözü, the main source of the Arykandos River.
\end{abstract}

Keywords: Kakasbos, Herakles, Dioskouroi, Helios, Nymphs, Arykanda, Lykia

\section{Öz}

İmparator III. Gordianus döneminde Arykanda için basılan sikke tipleri arasında daha önce bilinmeyen, yeni bir tip bulunmaktadır. Bu arka yüz tipinde Kakasbos, askeri kıyafetlidir ve bir Trakya miğferi takmaktadır. Bir elindeki lobutunu aşağıya doğru, diğer eliyle atının dizginlerini tutmaktadır ve yanında durduğu atı sağ ön toynağı ile Kakasbos'un yanında duran bir kayaya vurmakta ve bu kayadan sular fışkırmaktadır. Bu tip, daha önce Kakasbos için hiç rastlanılmamıs yeni bir tasvir tipidir; Kakasbos aslında hep atına binerken ve lobutunu vurmak üzere havaya kaldırmış şekilde tasvir edilmiştir. Bu makalede Arykanda'da kazılar sirasında bulunan epigrafik ve ikonografik çeşitli arkeolojik buluntular yardımı ile, bu tasvirin neden başka bir tanrı imgesi değil de, Kakasbos olduğu tartışılmaktadır. Yazarlar aynı zamanda, Arykandos Irmağı'nın ana kaynağ1 olan "Suyun Gözü" kaynağında sikke üzerinde yer alan su kaynağını ve yanındaki kült alanını tespit etmektedirler.

Anahtar Kelimeler: Kakasbos, Herakles, Dioskouroi, Helios, Nympheler, Arykanda, Lykia

* Assoc. Prof. Ahmet Tolga Tek, Anadolu Üniversitesi, Edebiyat Fakültesi, Arkeoloji Bölümü 26470 Eskişehir. Türkiye. E-mail: attek@anadolu.edu.tr ; https://orcid.org/0000-0002-3893-6256

Asst. Prof. Hacer Sancaktar, Yozgat Bozok Üniversitesi, Fen-Edebiyat Fakültesi, Arkeoloji Bölümü 66100 Yozgat. Türkiye. E-mail: hacer.sancaktar@bozok.edu.tr ; https://orcid.org/0000-0003-3268-7890

We would like to thank M. Tekinalp, director of the Arykanda excavations; the staff of the Antalya Archaeology Museum, especially the curators of the coin collection; C.S. Lightfoot; and Ö.C. Tasspinar for their invaluable help during the preparation of this work. 


\section{Introduction}

Twenty Lykian cities minted Roman provincial coinage only once - between AD 242-244 during the reign of Gordianus III. Although the minting was very brief, several cult-related types were employed for each minting city, and these coins provide a wealth of information on the "official cults" ${ }^{1}$ of these cities in the 3rd century AD. Of this coinage, 342 known examples were compiled by Hans von Aulock in Die Münzprägung des Gordian III und der Tranquillina in Lykien which was published in 1974. And even though 46 years have passed since it appeared, the book remains the main reference for this coinage. ${ }^{2}$ Since then, several hitherto unknown types, ${ }^{3}$ and for the existing types, new die variations or better-preserved examples that help with better identification, have been excavated or appeared on the market. All this new material adds more information on the Lykian cults represented on the coinage. While von Aulock worked on his book, archaeological excavations and surveys in Lykia were few in number. But since then excavations at Arykanda, Ksanthos, Letoon, Limyra, Myra, Andriake, Patara, Phaselis, Rhodiapolis and Tlos have progressed, and the results of extensive surveys at Balboura, Bubon, Kyaneai, Oinoanda, and Trebenna are now available. More importantly, a large number of new epigraphic discoveries made recently and other specific studies done on various topics in Lykia are constantly being published. All of these are increasing our knowledge immensely of Roman Lykia and its surrounding areas.

Arykanda was one of the most prolific mints among the 20 Lykian cities for issuing coinage under Gordianus III. Several different types employing different dies were minted for the city, and a large number of specimens have survived. For Arykanda, von Aulock listed 28 examples in his book. ${ }^{4}$ More than 20 new examples have appeared on the market since then, and 30 more coins of the city were excavated at Arykanda itself between 1971-2019. The new material contains some new types and variations to this coinage. Among them is a new type represented by 6 specimens ( 5 for Gordianus III, 1 for Tranquillina), on which the reverse presents an enigma with regard to the identity of the deity and the subject matter. This can only be solved by examining some of the other types and other cult-related objects found at Arykanda and coins minted elsewhere in Lykia. On the reverses of these coins, a male figure wearing military attire and a Thracian-type helmet holds the reins of his horse and a club and stands next to a water source (figs. 1-6). On first examination, the dress, horse, and club used as attributes

1 This means the types employed on the coinage would have been chosen by the cities themselves since they represent cults prevailing in these cities. They are sometimes also known from historical, epigraphic, and iconographic sources. We do not know how the mechanism worked, but one would imagine that the types were selected by city councils comprised of the civic elite. Thereby the coin iconography would have been an official testimony of the city for those years.

2 Until the appearance of RPC VII.2 which is in preparation by Marguerite Spoerri Butcher. She kindly informed us that the online version is expected to be available in 2020 at https://rpc.ashmus.ox.ac.uk/.

3 For example, Serapis at Gagai (CNG 93, 829; Apollo Kitharedeus at Kandyba (CNG Triton XVI, 708; Zeus at Korydalla (Künker 20, 803); Apollo and Hermes in an oracle (?) scene at Kyaneai (GM 199, 606), discussed below (fig. 15); hero (?) with Artemis Eleuthera at Kyaneai (Naville 36, 234); Apollo Surios at Myra (CNG 88, 915), discussed below (fig. 9); Asklepios and Hygieia or Apollo and a nymph at Myra (GM 147, 1847) discussed below (fig. 10); Aphrodite (?) and Eros (?) at Myra (MM 12, 222); Eros at Patara (Roma Numismatics E-sale 40, 411); cult image of Demeter shown on a basis at Phellos (CNG 93, 833). Athena throws a pebble into an urn at Phaselis (CNG Mailbid sale 69,1031 ), a scene which could be a likely reference to a sporting competition, as athletes are seen drawing their lots from a similar vessel on a coin of Prostanna (von Aulock 1979, 149, no. 1849, pl. 37). An agon called $\Pi \alpha \lambda \lambda \dot{\alpha} \delta \varepsilon \iota_{0}$ for Athena in the 3rd century AD is known from the city (Tüner-Önen 2015, 32). Or the type could be referring to delegate elections for the local boule or Lykian Koinon similar to the Koinoboulion figures present on coins of Tarsos and Anazarbos where the deity was also shown throwing a pebble into a vessel (see Ziegler 1999).

4 von Aulock 1974, 58-60, nos. 26-53. 
immediately bring to mind the figure of Kakasbos/Herakles. But the god is not named on the coin, and this type would present the god in a very unusual iconography that has not been encountered before. For this reason, all other possibilities of identification should be examined. The type clearly shows a local spring cult at Arykanda, and several similar cults are known from Lykia. ${ }^{5}$ All of these spring cults are associated with a patron deity, and some were even oracle centres.

\section{Catalogue}

\section{Gordianus III}

Obv: AYT KAI M ANT IOPAIANOC CEB; laurate, draped, and cuirassed bust $r$.

Rev: APYKAN- $\triangle E \omega N$; "Male deity" wearing Thracian helm, chlamys and cuirass standing facing, head turned right, holds club in left hand and leads horse with right. Horse's right foreleg is raised to strike vessel (hydria?) or rock with water flowing from inside.

Obv. same die with von Aulock 1974, no. 37, rev. same die with Tranquillina - no. 6 below

1 (fig. 1) Æ; 26,3g; 34mm; 12h; Exc. Inv. ARY 1998-42 (from Upper Agora, Shop 1 - East) = Tek 2002, no. 965 = Bayburtluoğlu 2003, 25 = Bayburtluoğlu 2006, 65, fig. 1.

2 (fig. 2) Æ; 18.08g (broken); GM142, 1997.

Obv: AYT KAI M ANT IOPAIANOC CEB; laurate, draped, and cuirassed bust $\mathrm{r}$.

Rev: APYKAN $\triangle \in \omega N$; "Male deity" wearing Thracian helm, chlamys and cuirass standing facing, head turned right, holds club in left hand and leads horse with right. Horse's right foreleg is raised to strike vessel (hydria?) or rock with water flowing from inside.

No. 3 same die with von Aulock 1974, no. 31; nos. 4 and 5, obv. same die with von Aulock 1974, no. 28; nos. 3-5 rev. from same die.

3 (fig. 3) Æ; 19,9g; 28/30mm; 10h; Exc. Inv. ARY 1990-146 (from rooms between Bouleuterion and Temple of Helios); Antalya Museum Inv: 7947 = Tek 2002, no. $968=$ Sancaktar 2019, no. S9.

4 (fig. 4) Æ; 19,0g; 28/29mm; 12h; Exc. Inv. ARY 1989-202 (from acropolis, YE 3, room 2); Antalya Museum Inv: $7537=$ Tek 2002, no. $967=$ Bayburtluoğlu 2003, 60 .

5 (fig. 5) Æ; 13,4g; 30/31mm; 12h; Exc. Inv. ARY 1979-135 (from Bouleuterion/Upper Agora); Antalya Museum Inv: $4402=$ Tek 2002, no. 966.

\section{Tranquillina}

Obv: CABEINIA TP-ANKYM EINA - [CE]; diademed and draped bust right set on crescent.

Rev: APYKAN- $\triangle \in \omega N$; "Male deity" wearing Thracian helm, chlamys and cuirass standing facing, head turned right, holds club in left hand and leads horse with right. Horse's right foreleg is raised to strike vessel (hydria?) or rock with water flowing from inside.

Obv. same die with von Aulock 1974, no. 47; rev. same die with Gordianus III - nos. 1-2 above.

6 (fig. 6) Æ; 22,11g; GM 152, 1801.

\section{River God Arykandos?}

The water flowing from a rock or vessel on the right side of the figure should probably associate this deity with the Arykandos River. ${ }^{6}$ In that case, could this be a representation of the

5 See Onur 2002a and Tiryaki 2006 for a general evaluation of spring cults and oracles in Lykia.

6 The Arykandos River (Akçay, Başgöz, Aykırıçay) is mentioned in Plin. Nat. Hist., V.XXVIII.100, “...iuxta mare Limyra eum amne in quem Arycandus influit...”; Plinius is describing the point where the Arykandos and Limyros (Göksu/ Saklısu) join (in modern Finike) and flow to the sea approximately $1500 \mathrm{~m}$. away. 
River God Arykandos? The answer would have to be negative since a quick survey ${ }^{7}$ of known river gods illustrated on Roman provincial coinage shows that they fall into two consistent types: either a half-dressed reclining male figure, usually with a vessel under his arm from which the water flows, or a swimming nude figure, and most of the times they are specifically named on the coins. These river gods could be shown alone or with other gods or heroes or in a mythological scene. Of the known coins of the twenty cities minting under Gordianus III in Lykia, only Limyra has one such type with its river god Limyros ${ }^{8}$ (fig. 7), shown in the usual manner reclining and with the river clearly named on the coin. It is surprising that rivers such as the Myros or the Ksanthos are not shown on these coins. ${ }^{9}$ What makes the coin type from Arykanda more interesting is that, an additional figure of a traditional reclining river god could have been easily incorporated to the type, next to the deity/hero in association with the water and with this way "the river god Arykandos" could have been shown, if one such representation of the river was wanted. Maybe the emphasis desired was to focus on the source itself and not the river. The pronounced water-discharging vessels of the river gods found on Roman coinage (as in fig. 7 ) is in contrast to the unidentifiable, roundish blob seen on the Arykanda coin. This makes one question whether this is not a hydria or an amphora at all, but rather the rock itself from which the spring flows.

Although river gods did not have an important part on Gordianus III's Lykian coinage, there are other coin types from various Lykian cities associated with water sources and various spring cults:

A coin type from Patara (fig. 8) depicts Dionysos on the left, holding his thyrsos and wearing a short chiton and a long chlamys and boots. On the right a nymph is sitting on rocks and supporting an urn on her knee; a goat (no horns visible so a baby goat or a lamb?) accompanies her. ${ }^{10}$ If it is a goat, it may be understood as Amaltheia, whose milk fed the infant Zeus, and the goat usually is shown accompanied by Nymphs. Dionysos himself was changed into a baby goat and nursed by nymphs when he was an infant. They later joined his company as the first of the Bacchantes. Although no water is shown on the coin type, the urn, the nymph sitting on a rock, and the goat-like animal signify that the type depicts a spring. ${ }^{11}$

This could be the "Telephos Spring", 7 stadia distant from Patara, mentioned by Stephanos of Byzantion. He took his information from Menaikhmos, saying that the spring was named after Telephos who washed his wound there and that its waters were cloudy/dirty because of

7 Imhoof-Blumer 1924; also the river gods catalogued at https://rpc.ashmus.ox.ac.uk/.

8 Illustrated example (fig. 7) is Savoca E-auc. 16, 389; type as von Aulock 1974, nos. 115-26; SNG Lewis II, no. 1668; for the ancient sources on Limyros, see Onur 2002a, 14, 53-56.

9 Unless new types are discovered in the future; see Onur 2002a and 2002b for the hydrography of Lykia.

10 von Aulock 1974, nos. 244-47; another unpublished example is in the Fethiye Museum collection (inv. no. 3984, 14.9g.). All known examples of this coin are very worn. The thyrsos is more visible on von Aulock 1974, pl. 13, no. 244. The example (Roma Numismatics E-sale 60, 556) illustrated here (fig. 8) belongs to a new and unrecorded coin hoard which the authors have noticed online. The hoard so far consists of 18 coins of Patara, all with similar patina. They were sold by the same company in various auctions during 2019 , and all labelled as "from the inventory of a German dealer". The actual contents, composition, and size of the hoard are unknown. Had the full contents of the hoard been known, it would have provided very important new information on coin circulation and usage in Lykia, as this would have been the first hoard (from Lykia?) known to have contained this coinage in significant numbers.

11 Goats accompany nymphs on several other coin types from various cities, especially the nymph Adrasteia/ Amaltheia (e.g., on coins of Dokimeon and Synnada in Phrygia, etc.). A coin of Aegae in Kilikia (RPC IV.3, no. 9547 temp.) shows another nymph that is very similar to the Patara type, sitting on the rocks accompanied by a goat with water flowing from an urn. 
that. ${ }^{12}$ Modern researchers associate the Telephos Spring with the modern Kokar Su, which contains sulphurous water that is still believed by local people to have healing powers. ${ }^{13}$

Obviously, one would expect Telephos himself to be depicted on a coin type that depicts a spring named after him. Therefore, the coin type may be referring to another spring and cult centre in the vicinity. ${ }^{14}$ An inscription from Oinoanda mentions a "spring of Nymphs together with Dionysos", which may be an oracle site of Apollo as understood from the rest of the inscription. ${ }^{15}$ So, the Patara coin may refer to a similar spring in the city's territory (maybe one related to the oracular cult of Apollo at Patara) which was thought to have belonged to Dionysos and a particular nymph or many nymphs. But the coin type and inscription bear no reference to an oracular cult.

Another city that had a famous water oracle is Myra, where at Sura there was an oracular centre. There the priests watched movements of sacred sea fish coming to feed from sticks with meat thrown in the water but were disturbed by the fresh water joining the sea in front of the oracle area. ${ }^{16}$ No coins of Myra had previously been recognized as featuring Apollo, but actually two types do exist and one may also refer to a nymph. ${ }^{17}$ The first coin (fig. 9) shows a statue of Apollo Propylaeus, using his bow, on a column with an elaborate capital on it. The statue is flanked by two laurel trees and in a space enclosed by a fence. ${ }^{18}$ One of the authors of this article (Tek 2001) associated this image with the cult image of Apollo Surios on the basis that none of the ancient authors actually mention a "temple" of Apollo Surios. Instead "a sacred grove of Apollo," from where the sea presumably would have been visible to the cult image, and the oracle happened at a place called "the Dinos/whirlpool." The inscriptions found on the walls of the existing temple on the valley floor next to Sura refer to the cults of Sozon and Zeus Atabyrus, and not Apollo. The only inscriptions referring to Apollo are found at the "priest hall" on top of the hill, not in the valley. A statue placed on a high column would ensure the visibility of the sea, and the two trees seen on the coin may actually refer to the sacred grove. Therefore, a possible "open-air shrine" of Apollo should be sought on the hill

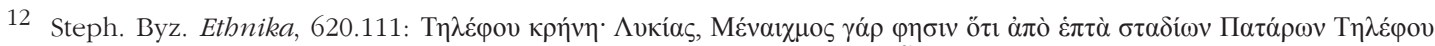

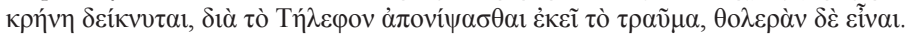

13 Onur 2002b, 55-56; Tiryaki 2006, 39; Sahin 2009, 345; 2012, 17, figs. 9-10, although Tiryaki is the only one among these researchers who refers to coin types using material from von Aulock 1974 for other cities. Unfortunately, Tiryaki did not mention this coin type from Patara, which was catalogued as featuring a nymph by von Aulock and others before him referenced in von Aulock's catalogue and in Frei 1990, 1818; also, an inscription from Patara refers to a priest of the nymphs, see TAM II.2, no. 416.

14 Such an unknown spring is placed between Ksanthos and Patara where, according to Ploutarkhos, the waters suddenly burst out and brought to light a plaque with an oracle written on it that prophesied the end of the Persian

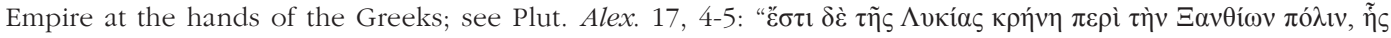

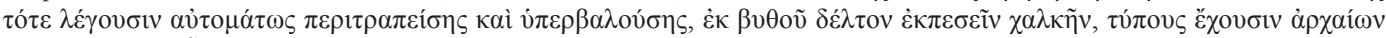

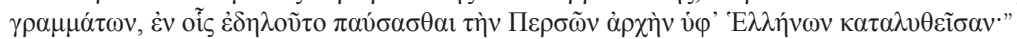

15 Milner 2000, 141, 143-45.

16 Borchhardt 1975, 76-79; Bryce 1986, 197-98; Frei 1990, 1762-764; Zimmermann 1992, 227-28. See Nollé 2006 for the most recent study on the oracle of Apollo Surios at Sura, which contains all the ancient references and related inscriptions recorded at the temple site in Sura together with references to other modern works.

17 Examples of both types were published by von Aulock 1974, nos. 169 and 170, but the coins remained unidentified because of their poor condition.

18 Illustrated example (fig. 9) is CNG 88, 915. Type as von Aulock 1974, no. 169; however, the figure there cannot be identified because of the condition of the coin. Another example of the coin was excavated in Arykanda and published in Tek 2001. A fourth and unpublished specimen exists in Ankara's Museum of Anatolian Civilizations as noted in Tek 2001, 239. See also von Aulock 1974, no. 222-24, Patara, for another coin type with Apollo Propylaeus. 
closer to the priest hall, which certainly had areas commanding the spring below and where the sea was (now silted), instead of on the valley floor. ${ }^{19}$

The other coin type from Myra (fig. 10) features, on the right, a semi-nude male figure (Apollo or Asklepios?) standing. He is leaning on a tree trunk with a snake coiled around it, and on his left there is a fully dressed female figure (nymph or Hygieia?) standing. ${ }^{20}$ The male figure is very similar to the others on coins of Patara, where one type especially shows a similar tree trunk around which a snake is coiled. The figure's hair is long and with a laurel wreath (?), similar to the archaistic hair shown on Apollo Patroos types. ${ }^{21}$ Apollo Patroos is fully clothed and his oracular powers are expressed by a raven sitting on an omphalos on one side and a snake coiled around a tripod on the other. The other type at Patara, on which a seminude Apollo feeds a snake from a patera, refers to another cult image. So if the figure on the right on the Myra coin is accepted as Apollo, then the female figure accompanying him must be a nymph referring to a spring. ${ }^{22}$ This brings to mind the so-called "nymphaion" building between Andriake and Myra from which a spring flows. ${ }^{23}$

Two similar coin types from Limyra also depict an oracular spring (fig. 11). ${ }^{24}$ On the coin types, a gazelle $e^{25}$ on the left and a zebu ${ }^{26}$ on the right are shown drinking (and in the second type only the gazelle is drinking while the zebu bellows) from presumedly a spring shown as two wavy lines with XPHCMOC ( $\chi \rho \eta \sigma \mu o ́ s=$ oracle) written on the coins. This scene is probably mythological, explaining the founding of the oracle there. Maybe Zeus is depicted in bull form or with the bull as his mythological animal; the nymph of the water source (or Artemis) is

19 Tek 2001, 240.

20 Illustrated example (fig. 10) is GM 147, 1847; type as von Aulock 1974, no. 170 but there remained unidentified owing to the condition of the coin.

21 von Aulock 1974, nos. 225-26, for a snake coiled around column; nos. 227-28, for a snake coiled around tree trunk; no. 193, pl. 12 is the best example where the archaistic long hair of Apollo Patroos is visible.

22 On the other hand, nothing on the coin type suggests any water source, such as a vessel from which water flows or a rock, as on the Patara coin discussed above (fig. 8).

23 For a brief description of the building, see Borchhardt 1975, 72-74. Since the harbour of Andriake is now silted up, it is harder to follow the ancient shoreline. But the "nymphaion" would have been across the ancient bay and not in Andriake. In fact, it was connected to the Sura acropolis by an ancient road still visible on the hill behind "the nymphaion" and closer to Sura than Myra, if the theatre signifies the ancient city centre. As a nymphaion, the building does not fit any usual Roman nymphaion architectural schema with an elaborately decorated high back wall and a pool in front. Instead the building has a square plan that looks as if it was a temple building, maybe with a Syrian-type pediment on its façade, where only the arch remains. The springs here, which form the Andriakos River, are thought to have healing powers by locals. One spring is called "Burguç", which is another word for "girdap" meaning "whirlpool". As the site is connected to the Sura acropolis and has a spring called "whirlpool", this could in fact be a better candidate for the location of the temple of Apollo Surios near a place called "Dinos/ whirlpool", than the temple in the valley floor at Sura where no inscriptions mention Apollo. The authors hope that the ongoing excavations at Myra and Andriake directed by Nevzat Çevik will confirm this hypothesis.

24 Type 1: von Aulock 1974, 109-11, both animals drinking water; type 2: von Aulock 1974, 112-13, gazelle drinking but zebu lifting its head up, possibly bellowing. Illustrated example (fig. 11) is von Aulock 1974, 111, and the coin is now in the Boston Museum of Fine Arts (inv. 1972.859) and belongs to type 1.

25 Although identified as a "dog" in von Aulock 1974, 109-13 and other references listed there, and by later researchers (e.g., Borchhardt 1999, 23 and Tiryaki 2006, 38), the animal is not a dog. It is in fact a Gazella subgutturosa (goitered or black-tailed gazelle). Its slender body, thin straight horns visible on the coin type, and uplifted tail are characteristics of this animal. This gazelle subtype still lives in Turkey and also has habitats in North Africa and West Asia. The breed probably originated in northwest Iran. Interestingly, this is an animal that is suited to steppes and arid environments, not humid river valleys or the Mediterranean coast. On the other hand, the artist may have simply meant a wild goat.

26 The Bos indicus or bos taurus indicus (indicine cattle or humped cattle) originated from India and was brought through Iran and bred in Turkey in antiquity, especially on the Taurus Mountains. It is an animal that can live in high altitudes and rocky environments. 
symbolized by the gazelle. Both have a part in the story. If that is the case, this story and cult may even have had an eastern, even Persian, origin with the choice of these particular animals that relate to Iran and beyond to the East. The wild mountain goat seen on the dynast Perikle's bronze coinage in the 4th century BC (fig. 12) ${ }^{27}$ may have symbolized one of the springs, with the gazelle (or again a wild goat badly executed on the Roman coin) replacing the goat some 700 years later. The reason why this may be a mythological scene instead of the actual oracle is because of Plinius' description of the Limyra oracle as another fish oracle. ${ }^{28}$

The River Limyros, which has two different sources - the ancient names unknown, the modern ones are Zengerler Kaynağ1 and Göksu Kaynağ 1 - both very close to each other and both inside Limyra, is where this oracle may have been situated. This presents another possible explanation for the coin type with the two animals symbolizing the names of the sources, similar to the way the Rivers Kapros and Lykos were shown sometimes on coins of Laodikeia in Phrygia as a boar and a wolf (fig. 13). ${ }^{29}$ So the Zebu bull (ßoṽ, or $\tau \alpha \tilde{v} \rho o \varsigma$ if only the bull was

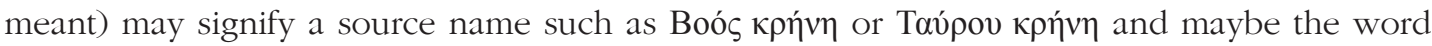

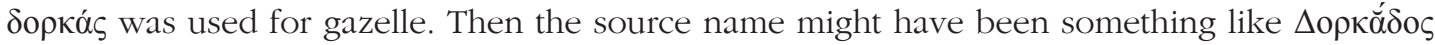

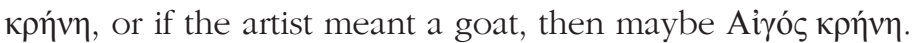

Kyaneai also has a coin type referring to an oracular source again with XPHCMOC ( $\chi \rho \eta \sigma \mu o ́ s$ $=$ oracle) written on the coin (fig. 14). ${ }^{30}$ In the type, Apollo is shown nude, holding a lowered bow $^{31}$ in his left hand and a branch (or a laurel crown) with ribbons in his right. With it he seems to touch the summit of rocks on his left, maybe creating the oracular source. ${ }^{32}$ A new coin type that appeared in the market probably shows another scene of this oracular spring (fig. 15). ${ }^{33}$ On the coin's reverse, the word $\chi \rho \eta \sigma \mu$ ó $\varsigma$ is not present, but Apollo is seen standing on the right holding a laurel branch, an altar is in the middle, and Hermes is holding his kerykeion and reclining on the rocks on the left. This oracle is identified with the one mentioned by Pausanias belonging to Apollo Thyrkseus; the water may show whatever the onlooker wishes. ${ }^{34}$ Its location may have been found during research conducted at the site. ${ }^{35}$

27 Illustrated example (fig. 12), is Roma Numismatics E-sale 39, 289; type as BMC Lyc. nos. 163-64, where its reverse was identified as a "stag".

28 Plin. Nat. Hist. XXXI.XVIII.22: item fluvii fons Limyrae transire solet in loca vicina portendens aliquid, mirumque quod cum piscibus transit. responsa ab his petunt incolae cibo, quem rapiunt adnuentes, si vero eventum negent, caudis abigunt.

29 For example, BMC Phr. nos. 52, 11-113, 127-29, 235, 260-61; illustrated example (fig. 13) is CNG 87, 850.

30 Illustrated example (fig. 14) is von Aulock 1974, no. 92; Robert 1977, 10, 13. The coin is now in Copenhagen, SNG Cop. Suppl., no. 510.1

31 It is clearly a bow, certainly not a water vessel (Wassergefäß) as claimed in Frei 1990, 1761.

32 A. Thomsen and F. Kolb interpreted this coin type as Apollo making an offering to a rock-cut altar (or a fire altar) such as those found in the territory of Kyaneai and elsewhere in Lykia (Thomsen 1995, 47; Kolb 2007, 283-85). The coin types shown in figs. 14 and 15 certainly very much resemble the rock-cut altars, but the oracle in Kyaneai is described as a water oracle. So one expects a coin that actually has "oracle" written on it to have something to do with the water. Hence, the interpretation presented here is the creation of a spring that would flow from the rocks. The ribbon-like object under the laurel branch or wreath could be water bursting or as suggested previously by Tiryaki 2004, 25-26, a snake, which would also have been fitting for an oracular scene dealing with Apollo. A detailed examination of the coin itself may resolve what the object is.

33 GM 199, 606.

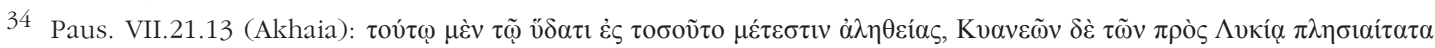

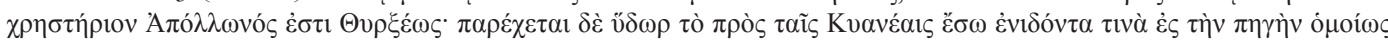

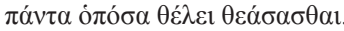

35 Kolb 1991, 201-3; Thomsen 1995; Öner 1998, 272-77; Kolb 2007, 283-85; Wurzer 2015, 89-92. 
Finally, a coin type from Arneai (fig. 16) depicts a nude nymph and Pan, and may also be another type that has connections with a local water source although the only relation of the type to water is the presence of the nymph. ${ }^{36}$ The type, according to J. Nollé, makes a pun on the city name Arneai with the Greek verb ápvéouar (to deny, to refuse), that is, the nymph saying no to the advances of Pan. ${ }^{37}$

Many other Lykian cities had sacred sources and related water cults, especially in Letoon, but these were not referred to on any known coin types. Such cult centres, and especially steles for the cult of Nymphs, have been discovered at several sites in Lykia. ${ }^{38}$ A stele excavated at Arykanda $^{39}$ (fig. 17) shows that a cult of Nymphs also existed here. But as discussed above, a single nymph or multiple nymphs were not used on the coin types of the town. This triad of nymphs on the stele, executed differently from others from Lykia, may be referring to the nymphs of the three different sources from which the town received its water.

To draw a general conclusion from the Lykian coin types discussed above, the water sources/springs apparently were considered more important than the rivers themselves. Some of these shown on these coins are oracular springs and always under the patronage of a god who may have played a role in the creation of the water source. Thereby, the coin types are more concerned with the mythological creation of the water source rather than of its flowing water. In fact, the Arykanda type is the only one besides the Limyros River type where the water is shown flowing. In conclusion, the Arykanda coin type does not show the image of a river god of the Arykandos River but instead the creation myth of the spring itself under a god's act of patronage.

\section{A Hero or Ktistes?}

As another option, the Arykanda coin type could be taken as illustrating a local hero (maybe a ktistes) in a mythological scene in connection with the founding of the city. Fortunately, two other coin types from Arykanda depict the actual ktistoi and the foundation oracle of the settlement. Therefore, a hero or a ktistes should be eliminated among the options to identify our subject matter type as they exist for Arykanda with their own specific coin type.

A coin sold in the market and now in the British Museum ${ }^{40}$ shows two figures wearing pilo $i$ and holding spears and the bridles of their horses and inscribed APYAC and KAN $\triangle O C$ on the reverse (fig. 18). The iconography obviously copies that of the Dioskouroi, but the names leave no doubt that these are the local ktistoi named Aryas and Kandos after whom

36 von Aulock 1974, no. 23. Purchased from H. von Aulock, the coin is now in the British Museum inv. 1978, 1021.3. L. Robert connected this type to the cults of Apollo and Tobaloas or Artemis Kombikes; see Robert 1955, 215-19. This type may be a reference to the source of Tokluca Çay1 which passes near the city; see Nolle 2009, 21-28 for an extensive study of this type. For the origins of the pantheon of Arneai, see Lebrun and Raimond 2015, 91 n. 70.

37 Nollé 2009, 27.

38 Robert 1955, 217-19; Naour 1976, no. 20; 1980, no. 42; Frei 1990, 1816-820; Milner 2000. The most recent study on the nymph steles and reliefs in Lykia is Dağl1 2011. Her catalogue contains a large group of nymph reliefs from Idebessos very close to Arykanda. One example, Dağl1 2011, no. 16, is a very well-preserved stele now in the Antalya Museum. It was acquired from Finike but might have come from Idebessos as well. The stele depicts nine female figures, and their attributes are visible. Some of them hold musical instruments like aula, syrinx, lyra, and flute. This shows that the Muses of Apollo were understood as nymphs in Idebessos and elsewhere in Lykia. See also Tiryaki 2018 for a newly discovered site near Elmalı where a rock relief situated on a water source shows Apollo and the "9 nymphs".

39 Bayburtluoğlu 2003, 177.

40 37.15g., 6h; Leu 52, 238=British Museum, inv. 1991,0619.1. 
the town was named. G. Neumann, who was the first to study and publish this coin, proposed that the original name of the city would have been Aruw-ak-anda meaning "the settlement in high rock" in Luwian/Lykian. This would fit the geography of the settlement on the slopes of a high mountain. He compared the names of Aryas and Kandos to other known eponym founders from Lykia like Tloos for Tlos and Pataros for Patara. ${ }^{41}$ All of these, and especially that of Arykanda, were probably made-up hero names to serve in made-up foundation stories created during Late Hellenistic and Roman times. For most examples, and probably for Arykanda as well, these names have nothing to do with the actual meaning of the place names in Luwian/Lykian/Milyan, whose meanings would have been lost with the death of these languages.

Another coin type minted for Arykanda should be examined in this context. The reverse shows an eagle standing on a wild boar's head (fig. 19). ${ }^{42}$ Such scenes are recognized as the main decisive moment of the foundation oracle with Zeus helping the founders by indicating the location for the settlement with his eagle. ${ }^{43}$ Nollé, who has recently collected and examined such stories from ancient sources and coin types from several cities in Asia Minor, states that "an eagle sent by Zeus swoops down from heaven, robs some sacrificial meat or bones burning on an altar and carries its prey away to a place, where Zeus wants a city to be founded by the very man who is offering the sacrifice". ${ }^{44}$ He presented the possible foundation story of Arykanda that would have been something like this: "the two eponymous heroes Aryas and Kandos succeeded in taking a boar. When the two heroes were offering its head as a sacrifice, an eagle stole it and took it to the place where these two warriors founded Arykanda and named it after themselves". 45

Even though the imagery of the founders in Figure 18 copies that of the Dioskouroi, there was in fact an actual cult of the real Dioskouroi in Arykanda. This cult was also very common at its other Milyas neighbours. But among the Lykian coins minted under Gordianus III, only on coins of Akalissos, another close neighbour of Arykanda, were the Dioskouroi shown. They were accompanied by an unidentified female goddess standing in the middle. ${ }^{46}$ Although reliefs and steles with the same triad are sometimes inscribed and name the Dioskouroi (sometimes as Soter) on them, the female goddess is almost never

41 Neumann 1991.

42 Illustrated example (fig. 19) is Auctiones A.G. 29, 361.

43 Nollé 2001, 46, 51-52; 2015, 46-47.

44 Nollé 2015, 78.

45 Nollé 2015, 46-47, 79, fig. 18a-18c.

46 von Aulock 1974, no. 1-2 identified her as Helena. The Dioskouroi accompanying a female deity were very common as a rural cult in southwest Asia Minor, but rarely shown on coinage, as noted by Horsley $1999,272$. Dioskouroi in Pisidia with Selene (?) or Artemis (?) wearing a crescent on her head are found at Isinda (von Aulock 1977, no. 796); at Kodrula (RPC IV.3, 3499 temp, 7306 temp, 7310 temp; von Aulock 1977, no. 1003, 1021) and at Termessos (SNG Pfps. Pisidien, no. 531). Usually at other Pisidian cities (e.g., Adada, Amblada, Ariassos, Konana, Pednelissos, Prostanna, Sagalassos, Verbe) where the Dioskouroi appear, the moon aspect was simply shown as a crescent between them. But similar iconography of the Dioskouroi with a female deity appears elsewhere too: at Tripolis in Phoenicia with turreted Astarte (RPC IV.3, 10138 (temp); at Alexandria with Demeter? wearing a kalathos (RPC III, 4217) and Selene(?) wearing a crescent on her head (RPC III, 4290, 4378) or a male deity, Ares at Metropolis in Ionia (RPC IV.2, 2686 [temp] and Serapis at Alexandria (RPC IV.4, 14776 [temp] and etc.). For the rock sanctuaries, inscriptions and reliefs of the cult of the Dioskouroi with a female deity in Lykia, Milyas, Kabalia and Pisidia, see Chapouthier 1935; Robert 1983, 563-65, 567; Frei 1990, 1784-786; Milner and Smith 1994; Delemen 1995; Smith 1997; Kearsley 2002; Özsait 2004; Özsait et al. 2004; Delemen 2011; Smith 2011, 138-40; İplikçioğlu and Schuler 2012; Renberg 2014, 112-16. 
named. ${ }^{47}$ These reliefs are usually found in association with open-air, rock-cut shrines in the countryside.

In contrast, several reliefs found at Arykanda come from inside the city and were excavated in the inhabited acropolis that was covered with houses and small sanctuaries. The reliefs were found separately from each other but in close proximity. This may indicate they came from a single, but yet unfound sanctuary, or maybe they were kept in house shrines. Almost all of the steles are fragmentary and weathered. But one stele is in an excellent state of preservation but, unfortunately its dedication inscription was chiseled away (fig. 20). Unlike the Aryas and Kandos coin where the heroes stand next to their horses, the Dioskouroi on the stele are shown riding theirs. ${ }^{48}$ Similarly, they wear military attire, hold spears, and wearing piloi. The goddess in the middle probably had a projecting attribute at the top of her head. Now lost, it may have been a crescent on a kalathos or a polos, or simply a crescent on the veil. ${ }^{49}$

Another very interesting Dioskouroi cult item excavated Arykanda is a very small golden medallion, unfortunately very much bent and battered (fig. 21). The Dioskouroi are here shown again riding with two stars above them to signify their cosmic roles. On this artefact, the triad is shown on a rectangular pedestal, like a statuary group. The middle figure, the female deity, wears a long kalathos without a crescent. The existing distance from the head of the deity to the upper side of the stele, discussed above (fig. 20), suggests that such a long kalathos may have also been present there too. The identity of the goddess still remains unknown from this new Arykanda evidence, but some candidates can be suggested with the help of evidence gathered from other finds.

At Arykanda, several altars to various cults of Artemis had been found, sometimes in close proximity with the Dioskouroi steles. The inscriptions name Artemis with no epithets as well as Artemis Lagbene, Artemis Kombike, Artemis Eleuthera, and Artemis Tharsenike. ${ }^{50}$ Although the first three epithets all belonged to the other cities of Lagbe, Komba, and Myra, the fourth may be local to Arykanda. It perhaps belongs to a countryside shrine as the epithet seems to name a toponym. Although not shown on the coinage, Artemis seems to have held a prestigious place among the cults practiced at Arykanda, as several vows and dedications were offered to her according to these altars and steles. The unnamed goddess on the Dioskouroi steles may be Artemis, but there are other female deity candidates at Arykanda. A new, unpublished dedicatory inscription mentions Demeter, and an altar to Nemesis is also known from the site. ${ }^{51}$

It is not possible to guess how the Arykandeans identified their Dioskouroi shown on the steles discovered here. Were they considered as Kastor and Polydeukes, or as Aryas and Kandos? But the absence of the goddess on the coin type seems to differentiate the two

47 She is named only on two examples. One is on an inscription from Bozhüyük near Elmalı where she seems to be named "Helena"; see İplikçioğlu and Schuler 2012. The second is at Macunasarı where she is named "Artemis"; see Robert 1983, 560, no. 10. Helena was the female part of this triad cult in Greece (Larson 2007, 189-92), but the visible mother goddess features on some of the steles, reliefs, and coin types from southwest Asia Minor seem to suggest that Helena here was mostly replaced by a local fertility/nature deity; see Delemen 2005, 162 n. 4 . For the Dioskouroi as Soter, see, for example, Milner and Smith 1994, 71; Delemen 2005, 161-62, no. DT 1, fig. 15.

48 As Delemen 1995, 298, type 1; but there also exists Type 2 where the Dioskouroi stand in front of their horses with the goddess in the middle.

49 Crescent on kalathos as Delemen 1995, nos. 2, 6, 8, 23, 32; crescent on polos as Delemen 1995, nos. 5, 31.

50 Şahin 1994, no. 85 (Kombike), no. 86 (Tharsenike and Thersenike), no. 87 (only Artemis); Bayburtluoğlu 2006, 63; Sancaktar 2019, 133-34 (four altars for Eleuthera), 134 (2 new altars for Kombike), 143 (two altars with inscriptions broken, but Artemis shown as Potnia Theron and Artemis Lagbene).

51 Sahin 1994, no. 84 
iconographies and therefore creates a barrier and distinction between them. Anyhow, the iconography of the Dioskouroi on the steles found at Arykanda and the ktistoi on the coin type in Figure 18 are very different from the water-source deity seen on the Arykanda coins in figs. 1-6. Therefore, the water deity is not a hero or ktistes but must be someone else.

\section{Kakasbos as the Source Deity?}

By eliminating all other possible candidates for the Arykanda coin type, only one is left. Kakasbos is the identity of the deity in connection with the water source, unless some new evidence is excavated that contradicts this identification. Yet, the iconography shown on the coin type is entirely new to Kakasbos and has never been seen before. As the coin does not name the deity and no inscriptional evidence is available from the excavated city limits or the territory of Arykanda in connection with this god, care is needed before such an identification is accepted. Kakasbos was merely one of the rider gods in southwest Asia Minor and several other candidates could be available. But the iconographic differences and geographical spread of these cults are helpful in determining the identity.

A Lykian funerary inscription from the period of the dynast Perikle of Zẽmuri (Limyra) and later ruler of Lykia (ca. 380-360 BC), recorded at Kiz1lca, north of the Elmalı Plain, is probably the oldest document where Kakasbos is epigraphically attested. ${ }^{52}$ The inscription contains the following phrase: "anybody who disgraces the tomb will be struck by Xaxakba". The name "Xaxakba" 53 has long been accepted as the Lykian name of Kakasbos. Quite possibly its roots contain the Anatolian etymon "hahatwa-" (to strike) and the Lykian word "asba-" (horse). ${ }^{54}$ Although the god began to be considered as a Lykian deity from this document written in Lykian script, ${ }^{55}$ the name is not encountered on any other inscriptions elsewhere in Lykia. The distribution of the rock cult sanctuaries and steles with good provenances points to the Milyas region both in north Lykia and southwest Pisidia for the origins and spread of this cult. ${ }^{56}$ The city of Khoma in Lykian Milyas, in whose territory Kiz1lca lay, seems to be a major centre of the cult as the city employed Kakasbos as a coin type during the Late Hellenistic period (fig. 34) and among the Gordianus III's Lykian coinage (fig. 35). Both will be examined below.

During the Late Hellenistic - Early Roman times, Kakasbos seems to be associated with Herakles because of the club attribute. ${ }^{57}$ On inscribed steles, rider gods holding clubs are

52 Bean 1971, 22-23, no. 38; Frei 1990, 1808; Zinko 2002, 232; Talloen 2015, 71.

53 R. Lebrun suggested that the reading should be transcribed as "Xaxasba". If true, the name Kakasbos preserved its original form; see Lebrun and Raimond 2015, 91 n. 72.

54 Lebrun 1998, 150-51; Locatelli 2015, 103-5; Lebrun and Raimond 2015, 84.

55 Horsley 1999, 37.

56 Talloen 2006, 749.

57 The most recent general work that contains an updated catalogue of Kakasbos and Herakles steles and reliefs is Drouin 2014. Numbers 1-46, all inscribed and dedicated to Herakles, have few known find places, disregarding doubtful examples reported to be from Rhodes and Miletos. Of the 46, the 8 known find places are at Pogla, Isinda, Uylupinar, Ali Fahrettin, Dereköy and Kemer near Tefenni, and 2 from Olbasa. If the provenances are considered indicative, this implies that the Herakles dedications mostly come from southwest Pisidia. Those inscribed with Kakasbos (also Kakasbas, Kakaob, Kakathibos, Trikasbos) are listed in Drouin 2014, nos. 47-92. 26 of the 45 have known provenances, disregarding unlikely provenances at Rhodes and Halikarnassos. Of the known find places, 3 are from Seki, 10 from north of Oinoanda, 1 from inside Oinoanda, 1 from Araksa, 1 from Çobanisa in the Elmalı Plain, Çavdır, Nebiler, Karaköy (near Fethiye), 5 from Fethiye, Yuva south of Tefenni, and Söğüt near Balbura. These provenances show that the cult of Kakasbos existed in western Lykia, Kabalia and Milyas, both in the Elmalı Plain and southwest Pisidia. Arykanda, merely 25 kilometers away from Kizılca where the earliest 
sometimes identified as Herakles, who also is named on the steles and also shown as a rider with a club. However, on some examples, iconographic differences between the two deities help to differentiate them. Herakles is usually nude and bearded and sometimes holds his club on his shoulder or upper arm, whereas Kakasbos is usually dressed in military gear and the club is always raised as if to strike. ${ }^{58}$ On the reverse of a recently published coin type of Sagalassos by H. Köker, a nude rider without a helmet holds a club raised to strike. The rider is identified as Herakles, not Kakasbos, because of the similar iconographic differences, especially to the rider figure on the Hellenistic Khoma coin type (fig. 34) discussed below. This new evidence pushes the date of this rider cult and its iconography in Pisidia well into the Hellenistic period, when the coin is dated. ${ }^{59}$

On the other hand, at Arykanda Herakles was probably never considered a rider god and was very clearly defined in his more usual Greek form as a coin type (fig. 22). ${ }^{60}$ At the site several works of art have a similar typology. Full-sized statue fragments, metal and bone statuettes, and marble sarcophagi with scenes of the twelve labours have been found. ${ }^{61}$ Here he was also worshipped as the gymnasium god together with Hermes. An inscription from the Heroon of Hermaios has an agonistic relief (fig. 23) that shows, starting from left, a nude standing Herakles (for heavy sports), a herm (Hermes for light sports), a tripod with a cauldron, a column with two vessels on it (maybe money bags?), a one-handled vessel for oil or lot drawing, another column with the object it was carrying broken away, and a further unidentified object (maybe a quiver?). ${ }^{62}$ In the inscription, it mentions that during Hermaios's term as gymnasiarch he dedicated agons to these gods. The evidence from Arykanda shows that there was no confusion here between the identities of Kakasbos and Herakles.

Why would Arykandeans not use a regular Kakasbos image on their coins that would have been easily understood? The answer lies with what they have done with the iconography of (and maybe the whole cult of) their chief deity Helios. ${ }^{63}$ At some point, maybe in the early 3rd century $\mathrm{AD}$, the entire iconography of Helios was changed into a rider god, borrowing all the iconographic features from Kakasbos. So, when one was needed for the actual Kakasbos, the standard iconography was already taken and a new one had to be created.

Arykanda joined the Lykian League only after the end of Mithridatic War between 88-84 BC, perhaps in $81 \mathrm{BC} .{ }^{64}$ Prior to the entrance of the city into the League, it had an autonomous

Kakasbos name form was recorded as "Xaxakba", seems to lie in the area that uses the name Kakasbos and not Herakles. See also Candaş 2006 for an analysis of the cult.

58 Delemen 1999, 7. Dressed examples are fewer (Drouin 2014, nos. 2-4, maybe 9, 17-22, 43, 45), but there are cuirassed examples as well (Drouin 2014, nos. 22, 35, 39, 42).

59 Köker 2019, 470-71, 475, fig. 1.

60 von Aulock 1974, nos. 38-40; illustrated example (fig. 22) is a new specimen excavated in Arykanda.

61 Bayburtluoğlu 2006, 63-64, fig. 5.

62 Şahin 1994, no. 162.

63 See Sancaktar 2019 for a detailed study on the cult of Helios at Arykanda, an architectural examination of the excavated temple, and various archaeological finds made at the temenos and related to the cult of Helios from other points in the site.

64 The Roman general Sulla, after winning the Mithridatic war, followed a policy of punishing the cities that had allied themselves with Mithridates, while rewarding Roman allies. When Sulla returned to Rome, he left Lucius Licinius Murena as his Legatus in Asia Minor. Murena probably was ordered to follow Sulla's policy, so between 84-82 BC he punished and abolished the Tetrapolis headed by Kibyra. Kibyra was attached to the province of Asia; Balboura and Bubon (and Oinoanda/Termessos Minor?) were given to the Lykian League (Strabo 13.4.17). See Magie 1950, 241-42; Mitchell 2005, 229; Kokkinia 2008, 18. In 81 BC, the Lykian League as a Roman ally during the Mithridatic War was rewarded by Rome; see Mitchell 2005, 231-32; Santangelo 2007, 122 n. 62. Rome probably formalized the 
coinage that included three different types, with all obverses depicting a head of Helios (fig. 24). ${ }^{65}$ This obverse type has been mistakenly described as "Sozon" in the literature, understandable in the light of similar busts employed on coinage elsewhere that are actually inscribed $\mathrm{C} \Omega \mathrm{Z} \Omega \mathrm{N}$ (fig. 25). ${ }^{66}$ But, while no inscriptions exist naming Sozon in Arykanda, the obverse type of the coinage was in fact copied from that of Helios on the coins of Rhodos (fig. 26). ${ }^{67}$ The similarities of the cult were recognized by the Rhodians. An anonymous follower of Pindaros described in an epigram, perhaps composed between the 4th and 2nd centuries $\mathrm{BC}$, the cult of Helios and its temple at Arykanda in the Hellenistic period. ${ }^{68}$ The temple was discovered and excavated by Cevdet Bayburtluoğlu in 1990 and dated to the 4th century BC. The identification was made possible by a number of altars found inside the temple and in its vicinity that named and portrayed the god (figs. 27-28). ${ }^{69}$ The temple seems to have been destroyed in the 2nd century AD, perhaps by the earthquake of AD 141/142 or some later, local calamity in the same century. The cult preserved its original nature up to this point as seen by the portrayal of the god on the altars (as in fig. 28) in a recognizable version of Helios similar to Hellenistic coins (fig. 24). ${ }^{70}$

When the cult was reorganized possibly in the early 3rd century $\mathrm{AD}$, a radical change was made regarding the god's image and possibly to the entire cult, syncretizing it with other cults. ${ }^{71}$ The new image shows Helios as a rider god, with his portrayal entirely copied from that of Kakasbos. He is raising a club to strike and wearing military attire, with the only difference

new territory given to the Lykian League, perhaps with the addition of further land towards the east, possibly parts of Milyas including Arykanda. A fragmentary inscription recorded at Korma (TAM II.3, no. 899), which is very near Arykanda, includes a Senatus Consultum with Sulla's name. Had it been complete, it would have been possible to understand how the Lykian League was rewarded. If the absence of Arykanda among the period I and II phases of Lykian League coinage and the fact that the inscription at Korma would probably had been a document that affected that community in particular are considered together, it can be presumed that Podalia, Arykanda, Idebessos, Akalissos, and Korma were probably included in the new territory given to the Lykian League. This would have strengthened the northeast border of the Lykian League both against Termessos Major and against the cities on the eastern coast of Lykia that had recently left the League and started cooperating with pirates. The entrance of Podalia into the Lykian League has also recently been discussed in more detail in Tek 2020 and in connection to other cities of the Lykian Milyas including Arykanda.

65 Illustrated example (fig. 24) is Auctiones A.G. 29, 360; type as Tek 2006, 776-77, nos. 50-51. A detailed study of the coinage of Arykanda is in preparation.

66 Sometimes as Sozon (?), for example, Head 1911, 694; Weinreich 1927, 1250; Frei 1990, 1827; Efendioğlu $2010,74$. This disregards the fact that all images of Sozon on coinage and steles (cf. Delemen 1999, nos. 286-91) are from Roman Imperial times, while the Arykanda coins discussed are Hellenistic. Although the cult of Sozon exists in Lykia at Kitanaura and Sura (cf. Frei 1990, 1826-827; Efendioğlu 2010, 74-78), no inscriptions recovered at Arykanda mention Sozon at all. Illustrated example (fig. 25) is a coin of Themisonium, Naumann 44, 723.

67 Illustrated example (fig. 26) is CNG EA. 266, 163 (19.10.2011)

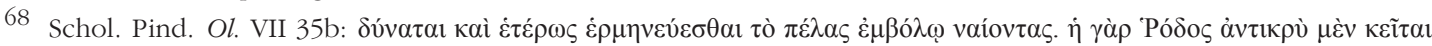

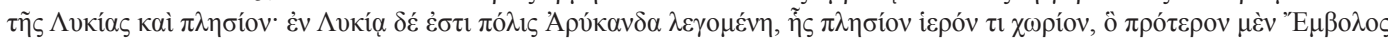

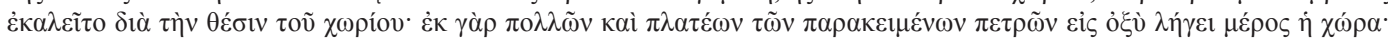

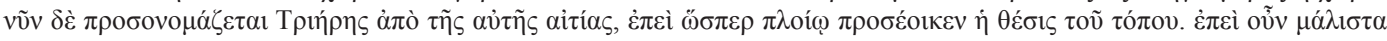

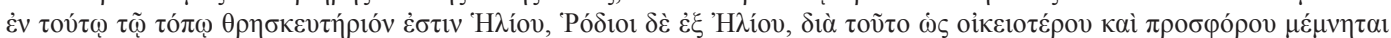

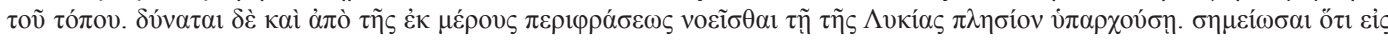

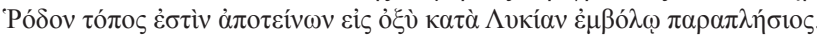

69 Bayburtluoğlu 1991, 229-30; 1992, 412. See Sancaktar 2019, 24-55, 63-79, 121-30, 132-33, 143 for a detailed description of the cult and the finds.

70 Sancaktar 2019, 143, pl. 72. The authors admit that it is almost impossible to date such local art, but these show the older version of the portrayal of the god and therefore should be earlier.

71 Zeus and maybe Apollo may have been included in the cult earlier. It is unclear who else was added in the 3rd century modifications. Mithras could be an option as there was a cult of Helios-Mithras in Oinoanda; see the dedication inscription, together with one for Hermes, one for Zeus, and one for the Dioskouroi (cf. Milner and Smith 1994, 71-72). 
being the rays spreading from his Thracian-type helmet. This is the image used as the most common coin type of Arykanda under Gordianus III (fig. 29). ${ }^{72}$ This rider image was also commonly confused and labelled as Sozon. But as Delemen pointed out in her extensive study of the rider gods, the Sozon rider images on steles hold diverse attributes such as a spear, double axe, or phiale but never a club. This was a feature of Kakasbos/Herakles/Maseis. ${ }^{73}$ The confusion in the identity of Arykanda's solar rider as Sozon was also noted by L. Robert, who instead pointed out the similarities of the type to Kakasbos. ${ }^{74}$

If the rider figure in Figure 29 is inspected closely, the deity is wearing a double chiton under his cuirass, with rider pants and boots underneath. These characteristics are also seen on a bronze rider figure found at the Temple of Helios (fig. 30) that portrays the god exactly as on the coin type. Although his horse and right arm are missing, the socket and the posture of the body shows that the arm was raised just as on the coin type. He was probably holding a club to strike while holding the reins in his left hand.

Did this new form of the god carry a different local name or epithet? The most important evidence identifying the new image of the god is a stele (fig. 31) excavated next to this bronze

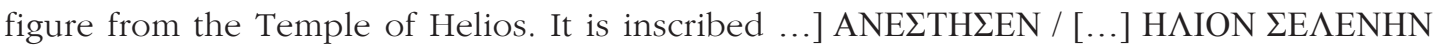
("dedicated by X, to [the gods $\mathrm{x}$ and] Helios and Selene"). The name Selene is written just under her figure, easily recognizable from her female form and the crescent on her shoulders. The name Helios is written under a standing figure who wears a double chiton, rider pants, and possibly boots while holding an empty horse's bridle in his hand. Therefore, the rider image on Arykanda coins (fig. 29) was in fact the town's chief deity Helios. Even though the new iconography for the god is syncretic, there was no change to the name of the god and no epithet was added. ${ }^{75}$

As seen on the stele in Figure 31, the surviving fragment shows at least three figures (there may have been five figures) with the names surviving for two. The figure in the middle can be identified as Zeus because of another coin type from Arykanda ${ }^{76}$ (fig. 32). Helios is seen on the

72 The most numerous specimens known from Arykanda under Gordianus III belong to this type, minted with several different dies. This indicates that the deity shown was the most important one here; see von Aulock 1974, nos. 2937, 48-50. Illustrated example (fig. 29) is CNG 93, 824.

73 Delemen 1999, 39 and nos. 286-91; also see Labarre et al. 2006, 104.

74 Robert 1946, 64-66 n. 1 on p. 66, which may have led Efendioğlu (2010, 83-84) to believe that the Arykanda coin type is showing Kakasbos. Efendioğlu (2008, 83, 92-93) also included in her Kakasbos catalogue coins of Akalissos, Korydalla, and Kyaneai (riders with spears), possibly missing Delemen's warning that "club" is the distinctive feature of Kakasbos. Riders with spears, such as those also seen on coins of Magnesia on the Maeander (Leukippos) or Kibyra (Kibyras) etc., should in fact be associated with eponymous founder heroes.

75 Syncretic names such as "Helios Zeus Mithras" or one of the names of the Anatolian rider gods with a solar aspect such as Sozon. Epithets might have been "victorious", "unbeaten", or simply "Arykandean" etc.

76 Illustrated example (fig. 32) is a new coin type excavated at Arykanda. This version of the type is unpublished in von Aulock 1974, but no. 47 in the catalogue is another version where the gods have changed places with Helios on the right and Zeus on the left. This is described by von Aulock wrongly as: "Gordian und Tranquillina? oder Sozon und Wagenlenker". Helios alone as a charioteer is a common image known from various artwork from antiquity. But Zeus accompanying him would be unique to Arykanda. Zeus could well be the third figure featured on the stele (fig. 31). If BMC Lyc., Arycanda, no. 3 truly belongs to Arykanda and not Ariassos, then he is another chief deity shown on the Hellenistic autonomous coinage of the town. A cult of "Zeus Nikator in the city" is named on an inscription from Kilepe near Arykanda (Wörrle 1996). S. Şahin (1994, 82) suggested that another epithet of Zeus

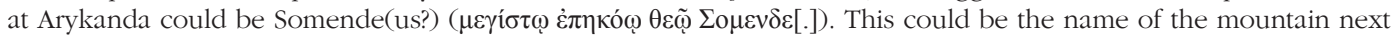
to Arykanda and just like Zeus Solymos of Termessos. Şahin with Adak $(2007,202)$ further suggested that a summit at Akdağ, for example Kizlar Sivrisi, could have been named Somenda. But finds from Bonda Hill near Limyra have proven that the name of the deity is Sumendis. His main cult center was probably here where several steles, altars, and pillars were erected for this god; see Marksteiner et al. 2007. Perhaps the person mentioned on the altar found at Arykanda (M. Aur. Heliodoros) had made a vow there and erected an altar at Arykanda for this god. 
left wearing a radiate Thracian helm, double chiton, and riding pants. His right hand is raised holding a club? (torch?) as if to strike, similar to his riding images above. On the right Zeus sits in a chariot holding a sceptre with his left hand, and a thunderbolt with his right. Both gods seem to be armed and ready to join a mythological battle.

Returning to the water deity on the coins (figs. 1-6) being discussed, while every aspect of this deity is very similar to Helios as rider discussed above (club, double chiton, rider pants, Thracian helmet), it can be seen that the main difference is the lack of rays on his helmet. Therefore, he cannot be Helios. We established above that he must have been Kakasbos and, as Kakasbos lost his typical rider image with club raised to strike to Helios, the Arykandeans had to invent a new iconography for the god on their coins. It was different from the traditional pose that had existed for him before. Obviously, they knew very well how Kakasbos should look, since they were very close to the centre of this cult.

A bronze figurine excavated at Arykanda (fig. 33) shows the god exactly as he is known from steles and rock reliefs: riding a (now missing) horse, right hand raised to strike, holding a (now missing) club, and wearing a cuirass and Thracian helmet. This bronze figurine is very similar to a Khoma coin type minted under Gordianus III (fig. 35). On the Hellenistic coinage of Khoma, which should be dated prior to $46 \mathrm{BC}$ when the town was incorporated into the Lykian League, ${ }^{77}$ the major type has a head of Zeus on its obverses. On the reverses a rider figure holds a club, raised as if to strike, in his right hand, while he holds the reins of his horse with his left. He is wearing a chlamys, cuirass, and crested Corinthian helmet (fig. 34). On the reverses of the smaller unit, the club itself becomes the main type inside a wreath. ${ }^{78}$ There are some changes to the iconography on the Gordianus III coins of Khoma. ${ }^{79}$ While the pose of the rider remains the same, the figure now wears a Thracian helmet, riding pants, and boots, exactly like the Arykanda examples (fig. 35).

The helmet seems to be especially particular to this part of Milyas in Asia Minor. ${ }^{80}$ This is not a Phrygian cap, but certainly a helmet with a brim/visor. Its back is visible on coins (figs. 1-6, 29, 32, 35) and on both bronze figures of Helios and Kakasbos (figs. 30 and 33). These helmets are very similar to the actual Thracian-type helmets excavated in Bulgaria, Romania, Macedonia, and Greece - ancient Thrace and Macedonia (fig. 36). ${ }^{81}$ This fascination with a cultural element easily identified as "Thracian" used for two chief deities at Arykanda - Helios and Kakasbos - may well be related to the fact that the Arykandeans identified themselves as Thracians or of Thracian descent. ${ }^{82}$

The coin type in figs. 1-6 emphasizes the horse's right front leg, which is shown longer, lifted, and touching the water source. The horse is in fact striking the rock and creating the

\footnotetext{
77 Mitchell 2005, 169, line 54.

78 See Tek 2006, 777, nos. 56-57, figs. 30-32 for the types and dating of the Hellenistic coinage of Khoma.

79 von Aulock 1974, no. 54. Apart from the new coin excavated at Arykanda (Tek 2002, no. 974) illustrated here (fig. 35), two more examples of this rare coin have appeared on the market: CNG 93, 826 and Paul-Francis Jacquer $38,215$.

80 Possibly also at Idebessos. See Delemen 1996 for similar bronze Kakasbos figurines from Idebessos.

81 For example, such as those in Schröder 1912; Andronicos 1979; Fol and Inkova 1998; Dimitrov 2002-2003; Juhel and Sanev 2011. This type is classified as "tiaraartige helm (tiara like helm)" in Dintsis 1986, 23-56.

82 Plin. Nat. Hist., V.95: "a latere autem eius super Pamphyliam veniunt Thracum suboles Milyae, quorum Arycanda oppidum". But this Thracian element is not particular to Arykanda, but also common to the rest of the Milyas cities. For example, the people of Arykanda's northern neighbour Podalia were called Thracian: Steph. Byz. Ethnika

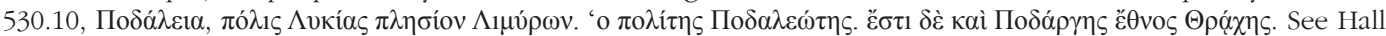
1986, 152-54, for the rest of the evidence on Thracians in Milyas.
} 
spring. This recalls Pegasos creating the source called Hippokrene on Mount Helikon by striking the rock there. ${ }^{83}$ By this aspect, Pegasos was regarded as the horse of the Muses, perhaps more celebrated as such in modern times than antiquity. The Hippokrene source was an "inspiring well/source of the Muses". ${ }^{84}$ The Lykians would have been very familiar with the stories of Bellerophon and Pegasos. Arykandeans, once again being creative, adopted these Pegasos myths on the creation of Hippokrene and elsewhere to their water source and to the horse of their god Kakasbos. But there is no evidence about what the sacred waters of the Arykanda source were supposed to do, such as inspiring, giving oracles, or healing. ${ }^{85}$ So, to sum up, Kakasbos was the protector of the source at Arykanda, and it was his horse that actually created it. ${ }^{86}$

One needs to go no further than Suyun Gözü, the main water source at Arykanda, to discover what the coin type meant as this sacred spring. Was it called another Hippokrene or possibly, in Arykanda's case, Kakasboukrene? The water source here is situated on the west side of the city, and the area also marks the starting point of the earlier necropolis (figs. 39-40). Here most of the Lykian-type rock tombs exist, although none are inscribed in Lykian. ${ }^{87}$ The rock façade forming the southeast side of the water source was carved with several rectangular slots $^{88}$ for the placement of steles, all now missing (fig. 40). Photographs of the area taken in 1892 (fig. 37$)^{89}$ and in $1954^{90}$ (fig. 38) show that this rock sanctuary was higher than the road (seen in fig. 37) and majestically visible to travellers. Unfortunately, the whole area in front of the sanctuary is now filled in to a height of several meters by modern road construction and by the creation of a modern market area. But the rock sanctuary and the water source are still visible behind the market stalls.

Today it takes a lot of effort to understand the diverse and fascinating types employed on Arykanda's coinage and why the civic cults were represented in such a complicated way. But these images were well known and easily recognized by the local population for whom the coins were minted. For one moment between AD 242-244 when these coins were minted, we delve into the "official testimony" of the cults in the city via types selected by the city elite who decided what was to be minted. The picture we see is a complex transformation, very different

83 Aratus Phaen., 205-25; Strabon 8. 6. 20; Paus. 9. 31. 3; Ant. Lib. Met., 9; Hyginus Astronomica, 2. 18; Ovid. Fasti 3.449-58; Ovid. Met., 5.254-56; Nonnos, Dionysiaca, XLIV. 6-9. There were other water sources and wells believed to have been created by Pegasos at Trozene (Paus. 2.31.9) and Peirene in Corinth (Statius Thebaid, IV.60).

84

This raises the question of how the 9 figures seen on steles in Lykia were understood - as plain nymphs or as inspiring Muses? Possibly, many "inspiring" sources like Hippokrene existed in Lykia. On the 10 reliefs and steles known from Lykia with 7 or more figures (cf. Dağlı 2011, no. 8-18), the female figures usually hold musical instruments like Muses. In Naour (1976, no. 20=Dağlı 2011, no. 9, there are ten figures with the larger one on the extreme right holding a kithara. So he is Apollo seemingly with his nine Muses. Apollo is also next to nine female figures at the Yukarıvacık relief (cf. Tiryaki 2018). On the other hand, out of these 10 representations (cf. Dağl1 2011, nos. 13, 15, 17-18), the present inscriptions clearly name them as nymphs. In that case, the sources they were connected to may have been "inspiring" ones that copy the Hippokrene.

85 R. Lebrun and É. Raimond $(2015,98)$ considered the cult of Kakasbos as an oracular one.

86 Kakasbos was also connected to a spring at Yarıkpınar in Balboura's territory; see Smith 1997, 18.

87 Unfortunately, some of the rock tombs closest to the water source were damaged and destroyed when the Elmal1Finike highway was constructed in the 1960s. The construction enlarged and filled in the sides of the ancient road that existed here.

88 Four stele slots still exist, and their measurements from south to north are: (1) h. 92 x w. 65 cm; (2) h. 110 x w. 59 cm; (3) h. 134 x w. $102 \mathrm{~cm}$; and (4) h. 151 x w. $113 \mathrm{~cm}$.

89 Krickl 2005, 127, no. II.28

90 Onat 1954. 
from what was shown on Hellenistic examples. At Arykanda, the excavations have provided more clues for numismatics, such as steles, inscriptions, and sculpture, to identify who and what was meant on the coin types. It makes one wonder how many more clues are waiting to be discovered for other unexplored mints where no such evidence is (as yet) available and the researcher is left only with the coin types. 


\section{Bibliography}

\section{Ancient Sources}

Ant. Lib. Met., Antoninus Liberalis, The Metamorphoses of Antoninus Liberalis with an English translation by F. Celoria. 1992. London/New York: Routledge.

Aratus Phaen., Callimachus, Lycophron, Aratus. Hymns and Epigrams. Lycophron: Alexandra. Aratus: Phaenomena. Translated by A.W. Mair and G.R. Mair. 1921. The Loeb Classical Library 129. Cambridge, MA: Harvard University Press.

Hyginus Astronomica Hyginus, Hygini Astronomica, edited by B. Bunte. 1875. Wiegel: Leipzig.

Nonnos, Dionysiaca, Nonnos, Dionysiaca, Vol. 3, books 36-48, H.J. Rose and L.R. Rind, 1942. The Loeb Classical Library 356. Cambridge/London: Harvard University Press.

Ovid. Fasti, Publius Ovidius Naso, Fasti (I-VI) Roma Takvimi ve Festivaller. Translated by A.C. Abuagla 2016. Istanbul: Yapı Kredi Yayınları.

Ovid. Met., Ovidius, Ovid Metamorphoses, F.J. Miller, Vols. 3-4. Revised by G.P. Goold. The Loeb Classical Library 42. 2005. Cambridge, Mass./London: Harvard University Press.

Paus. Pausanias, Description of Greece with an English translation by W.H. Jones, Vol. 1; 3-4; W.H. Jones and H.A. Ormerod, Vol. 2; R.E. Wycherley, Vol. 5 (Illustrations and Index). New York 1918-2004. The Loeb Classical Library: Harvard University Press.

Plin. Nat. Hist., Plinius the Elder, Pliny, Natural History, Vol. 2, Libri 3-7 ed. H. Rackham, Cambridge MA and London, 1961. The Loeb Classical Library: Harvard University Press.

Plin. Nat. Hist., Pliny, Natural History, Vol. 8, Libri 28-32, ed. W.H.S. Jones, 1963, Cambridge, MA and London. The Loeb Classical Library: Harvard University Press.

Plut. Alex.,Ploutarkhos, Plutarkh's lives - Alexander with an English translation by B. Perrin London/New York 1919. The Loeb Classical Library: Harvard University Press.

Schol. Pind. Ol., School of Pindaros, "Olympian Odes" inside Pindar Nemean Odes. Isthmian Odes. Fragments. Edited and translated by W.H. Race. 1997. The Loeb Classical Library. Cambridge, Mass./London: Harvard University Press.

Statius, Thebaid, Statius, Thebaid, Books 1-7, D.R. Shackleton Bailey, Loeb Classical Library, 2003.

Steph. Byz. Ethnika, Stephanos of Byzantion, Stephani Byzantii, Ethnica, Vol. 4, edited by M. Billerbeck and A. Neumann-Hartmann, 2016. Berlin/Boston: Walter de Gruyter.

Strabon, Strabon, Geographika. Edited by A. Meineke, 1877. Leipzig: Teubner.

\section{Modern Works}

Andronicos, M. 1979. "The Finds from the Royal Tombs at Vergina." ProcBritAc 65:355-67.

Bayburtluoğlu, C. 1991. "1990 Arykanda Kazısı." Kazı Sonuçları Toplantısı 13.2:227-33.

Bayburtluoğlu, C. 1992. "1991 Arykanda Kazısı Raporu." Kazı Sonuçları Toplantısı 14.2:409-13.

Bayburtluoğlu, C. 2003. Arykanda. Yüksek Kayah̆̆ın Yanındaki Yer. Istanbul: Homer Kitabevi.

Bayburtluoğlu, C. 2006. "Arykanda Tanr1ları ve Kültleri." In The IIIrd International Symposium on Lycia. 07-10 November 2005, Symposium Proceedings. Antalya. 2 vols., edited by K. Dörtlük, B. Varkıvanç, T. Kahya, J. des Courtils, M. Doğan Alparslan and R. Boyraz, 61-68. Istanbul: AKMED.

Bean, G.E. 1971. Journeys in Northern Lycia 1965-1967. Ergänzungbände zu den Tituli Asiae Minoris 4. Vienna: Hermann Böhlaus Nachf.

BMC Lyc. Hill, G.F. 1897. A Catalogue of the Greek Coins in the British Museum, Catalogue of the Greek Coins of Lycia, Pamphylia and Pisidia. London: Printed by Order the Trustees of the British Museum. 
BMC Phr. Head, B.V. 1906. A Catalogue of the Greek Coins in British Museum. Catalogue of the Greek Coins of Phrygia. London: Printed by Order the Trustees of the British Museum.

Borchhardt, J., ed. 1975. Myra. Eine lykische Metropole in antiker und byzantinischer Zeit. IstForsch 30. Berlin: Gebr. Mann Verlag.

Borchhardt, J. 1999. Limyra, Zemuri Taşları. Istanbul: Arkeoloji ve Sanat Yayınları.

Bryce, T.R. 1986. The Lycians. Vol. 1, The Lycians in Literary and Epigraphic Sources. Copenhagen: Museum Tusculanum Press.

Candaş, A. 2006. "The Kakasbos/Herakles Cult: A Study of Its Origins, Diffusion and Possible Syncretisms." Master's thesis, Bilkent University.

Chapouthier, F. 1935. Les Dioscures au service d'une déesse. Étude d'iconographie religieuse. Paris: de Boccard.

Dağlı, İ. 2011. "Nympheler ve Lykia'dan Nymphelere Adanmış Kabartmalar.” Master's thesis, Istanbul University.

Delemen, İ. 1995. "Lykia-Kabalia-Pisidia Bölgesinden Roma Dönemi Dioskurlar ve Tanrıça Kabartmaları." Belleten 59.225:295-321.

Delemen, İ. 1996. "Lykia-İdebessos’ta Bulunmuş Olan Bronz Adak Heykelcikleri." Anadolu Araştırmaları 14 (Prof. Dr. Afif Erzen'e Armağan):197-212.

Delemen, İ. 1999. Anatolian Rider-Gods: A Study on Stone Finds from the Regions of Lycia, Pisidia, Isauria, Lycaonia, Phrygia, Lydia and Caria in the Late Roman Period. Asia Minor Studien 35. Münster: Dr. Rudolf Habelt.

Delemen, İ. 2005. "Halûk Perk Müzesi'ndeki Thrak ve Anadolu Atlilar1." Tüliya 1:149-76.

Delemen İ. 2011. "Dioskurlar ve Tanrıça: Sadberk Hanım Müzesi’ndeki Bir Gümüş Aplik.” Özsait Armağanı: Mehmet ve Nesrin Özsait Onuruna Sunulan Makaleler, edited by H. Şahin, E. Konyar, and G. Ergin, 143-47. Istanbul: AKMED.

Dimitrov, S. 2002-2003. "Helmets from Ancient Thracia." Известия. Bulletin of the Regional Museum of History of Veliko Turnovo (Изследвания и материали om VI музейини четения, посветени на 70 годишния юбилей на доц. д-р Янка Николова 17-18 май 2002 г., Белико Търново. Studia in Honorem Janko Nikolova) 17-18:179-88.

Dintsis, P. 1986. Hellenistiche Helme. Vol. 1, Text. Archaeologica 43. Roma: G. Bretschneider.

Drouin, M. 2014. "Les cultes d'Héraklès et de Kakasbos en Lycie-Pisidie à l'époque impériale romaine. Étude des stèles dédiées aux dieux cavaliers à la massue." Master's thesis, Laval University.

Efendioğlu, T. 2008. "Hellenizm ve Roma Çağları Likyası'nda Yerel Kütler.” Master's thesis, Marmara University.

Efendioğlu, T. 2010. Hellenistik ve Roma Çağlarında Likya'da Yerel Tanrı ve Tanriçalar. Istanbul: Arkeoloji ve Sanat Yayınları.

Fol, V., and V. Inkova. 1998. "Thracian Helmet from the Village of Pletena, Western Rhodope." Orpheus. Journal of Indo-European and Thracian Studies 8 (Memorial Volume of Vladimir I. Georgiev):21-34.

Frei, P. 1990. "Die Götterkulte Lykiens in der Kaiserzeit." ANRW2.18.3:1729-864.

Hall, A.S. 1986. "R.E.C.A.M. Notes and Studies No. 9: The Milyadeis and their Territory." AnatSt 36:137-57.

Head, B.V. 1911. Historia Numorum. A Manual of Greek Numismatics. New and enl. ed. Oxford: Clarendon Press.

Horsley, G.H.R. 1999. The Rider God Steles at Burdur Museum in Turkey. Museum of Antiquities Maurice Kelly Lecture 3. Armidale N.S.W: Universiy of New England.

İplikçioğlu, B., and C. Schuler. 2012. "Ein Tempel für die Dioskuren und Helena, Eine neue Bauinschrift aus Bozhüyük bei Elmalı im lykischen Hochland." AnzWien 146.2:39-60. 
Imhoof-Blumer, F. 1924. "Fluss- und Meergötter auf griechischen und römischen Münzen (Personifikationen der Gewässer)." SNR 23:171-421.

Juhel, P., G. Sanev. 2011. "A New Helmet from Macedonia." In Hellenistic Warfare 1: Proceedings of the First International Conference on Hellenistic Warfare. edited by N.V. Sekunda and A.N. Borel, 155-78. Instituto Valenciano de Estudios Clásicos y Orientales 2, Fundación Libertas 7. Valencia: Gráficas Mari Montañana S.L.

Kearsley, R.A. 2002. "Cultural Diversity in Roman Pisidia: The Cult of the Dioskouroi." In Actes du 1er Congrès international sur Antioche de Pisidie. Collection de l'Institut d'archéologie et d'histoire de l'antiquité 5, edited by T. Drew-Bear, M. Taşlıalan, and C.M. Thomas, 401-10. Paris: Diffusion de Boccard.

Kokkinia, C. 2008. "Introduction." In Boubon. The Inscriptions and Archaeological Remains. A Survey 2004-2006, edited by C. Kokkinia, 1-25. Meletemata 60. Athens: Diffusion De Boccard.

Kolb, F. 1991. "Kyaneai 1989. Vorbericht über Feldforschungen im Yavu-Bergland bei Kaş mit Beiträgen von W. Böser, V. Höhfeld, F. Kolb, B. Kupke, M. Miller, A. Rieger, and M. Zimmermann." IstMitt 41:187-264.

Kolb, F. 2007. "Akkulturation in der lykischen 'Provinz' unter römischer Herrschaft." Tra Oriente e Occidente. Indigeni, Greci e Romani in Asia Minore. Atti del convegno internazionale, Cividale del Friuli, 28-30 settembre 2006, edited by G. Urso, 271-91. Pisa: Edizioni ETS.

Köker, H. 2019. "Kakasbos/Herakles (?) ve Yeni Bir Bronz Sagalassos Sikkesi." Olba 27:465-75.

Krickl, E. 2005. 1892 Lykia Günlüğ̈̈̈, edited by N. Başgelen, translated by F.D. Öztürk and Z.Z. İlkgelen. Istanbul: Arkeoloji ve Sanat Yayınları and Suna ve İnan Kıraç Vakfı.

Labarre G., M. Özsait, and N. Özsait. 2006. "Les reliefs rupestres de Tefenni (Pisidie)." Anatolia Antiqua 14:89-115.

Larson, J. 2007. Ancient Greek Cults: A Guide. New York/London: Routledge.

Lebrun, R. 1998. "Panthéons locaux de Lycie, Lykaonie et Cilicie aux deuxième et premier millénaires av. J.-C." Kernos 11:143-55.

Lebrun R., and É. Raimond. 2015. "Les divinités et les cultes en Lycie." Hethitica 17:79-116.

Locatelli, L. 2015. "Le cheval dans l'onomastique du Sud-Ouest de l'Anatolie." Babelao 4:101-10.

Magie, D. 1950. Roman Rule in Asia Minor. To the End of the Third Century After Christ. 2 vols. Princeton, NJ: Princeton University Press.

Marksteiner, T., B. Stark, M. Wörrle, and B. Yener-Marksteiner. 2007. "Der Yalak Baş1 auf dem Bonda Tepesi in Ostlykien. Eine dörfliche Siedlung und ein ländlicher Kultplatz im Umland von Limyra." Chiron 37:243-93.

Milner, N.P., and M.F. Smith. 1994. "New Votive Reliefs from Oinoanda." AnatSt 44:65-76.

Milner, N.P. 2000. "Notes and Inscriptions on the Cult of Apollo at Oinoanda." AnatSt 50:139-49.

Mitchell, S. 2005. "The Treaty between Rome and Lycia of 46 BC." Papyrologica Florentina 35:163-258.

Naour, C. 1976. "Inscriptions et reliefs de Kibyratide et de Cabalide." ZPE 22:109-36.

Naour, C. 1980. Tyriaion en Cabalide: épigraphie et géographie historique. Studia Amstelodamensia ad Epigraphicam, Ius Antiquum et Papyrologicam pertinentia 20. Zutphen: Terra Publishing Co.

Neumann, G. 1991. "Der lykische Ortsname Arykanda." Historische Sprachforschung/Historical Linguistics 104.2:165-69.

Nollé, J. 2001. Die Abwehr der wilden Schweine. Schwarzwildjagden im antiken Lykien. München: Biering \& Brinkmann.

Nollé, J. 2006. "Königliches Gefolge beim Fischorakel von Sura." In The IIIrd Symposium on Lycia. Symposium Proceedings. Antalya, 07-10 November 2005. 2 vols., edited by K. Dörtlük, B. Varkıvanç, T. Kahya, J. des Courtils, M. Doğan Alparslan, and R. Boyraz, 515-22. Istanbul: AKMED. 
Nollé, J. 2009. "Beiträge zur kleinasiatischen Münzkunde und Geschichte 6-9." Gephyra 6:7-99.

Nollé, J. 2015. "Beiträge zur kleinasiatischen Münzkunde und Geschichte 11. Adleromina: Stadt- und Kultgründungen auf Geheiß des Zeus." Gephyra 12:1-88.

Onat, B. 1954. Antalya'dan Resimler. Antalya: Basın Yayın ve Turizm Genel Müdürlüğü.

Onur, F. 2002a. "Lykia Hidrografisi." Master's thesis, Akdeniz University.

Onur, F. 2002b. “Antik Veriler Işı̆ğnda Lykia'nın Hidrografyası.” In Lykia Incelemeleri 1, edited by S. Şahin and M. Adak, 53-61. Istanbul: Arkeoloji ve Sanat Yayınları.

Öner, E. 1998. "Naturgeographie und Mensch-Umwelt-Beziehungen im Yavu-Bergland.” In Lykische Studien 4, Feldforschungen auf dem Gebiet von Kyaneai (Yavu-Bergland). Ergebnisse der Kampagnen 1993-94, edited by F. Kolb, 267-81. Asia Minor Studien 29. Bonn: Dr. Rudolf Habelt.

Özsait, M. 2004. "Nouveaux témoignages sur le culte des Dioskouroi en Pisidie occidentale." In Les cultes locaux dans les mondes grec et romain. Actes du colloque de Lyon, 7-8 juin 2001, edited by G. Labarre, 103-12. Lyon: Université Lumière-Lyon 2/Paris: Diffusion de Boccard.

Özsait M., G. Labarre, and N. Özsait. 2004. "Les reliefs rupestres et les inscriptions de Keçili-Yanıktaş (Pisidie)." Anatolia Antiqua 12:61-82.

Renberg, G.H. 2014. "Unexplored Aspects of the Lycian Twelve Gods Reliefs.” EpigAnat 47:107-32.

Robert, L. 1946. "Un dieu anatolien: Kakasbos.” Hellenica 3:38-73, 173-74, pl. 1-6.

Robert, L. 1955. "Villes et monnaies de Lycie." Hellenica 10:188-222.

Robert, L. 1977. "Monnaies hellénistiques." $R N$ 19:7-47.

Robert, L. 1983. "Documents d'Asie Mineure: XXVII. Reliefs Votifs." BCH 107:511-99.

RPC III Amandry M., and A. Burnett. 2015. Roman Provincial Coinage III, Nerva, Trajan and Hadrian (AD 96-138). London: The British Museum Press.

RPC IV Heuchert V., and C. Howgego. Roman Provincial Coinage IV (The Antonines) Online catalogue (with temporary numbers) [Roman provincial coinage online]. http://rpc.ashmus.ox.ac.uk/coins/

Sancaktar, H. 2019. Arykanda I. Arykanda Akropolisi Kutsal Alanlar ve Kültleri. Ankara: Bilgin Kültür Sanat Yayınları.

Santangelo, F. 2007. Sulla, the Elites and the Empire. A Study of Roman Policies in Italy and the Greek East. Impact of Empire 8. Leiden/Boston: Brill.

Schröder, B. 1912. "Thrakische Helme." Jdl 27:317-44.

Smith, T.J. 1997. "Votive Reliefs from Balboura and Its Environs." AnatSt 47:3-49.

Smith, T.J. 2011. "Highland Gods: Rock-cut Votive Reliefs from the Pisidian Survey." AnatSt 61:133-50.

SNG Cop. Suppl. Schultz S., and J. Zahle. 2002. Sylloge Nummorum Graecorum. The Royal Collection of Coins and Medals. Danish National Museum. Supplement: Acquisitions 1942-1996. Copenhagen: Nationalmuseet.

SNG Lewis II. Carradice, I.A. 1992. Sylloge Nummorum Graecorum. Great Britain, Vol. VI, The Lewis Collection in Corpus Christi College, Cambridge, Part II: The Greek Imperial Coins. Oxford/New York: Oxford University Press.

SNG Pfps. Pisidien. Nollé, J. 1999. Sylloge Nummorum Graecorum. Deutschland. Pfälzer Privatsammlungen. Vol. 5, Pisidien und Lykaonien, Nr. 1-586. Munich: Hirmer Verlag.

Şahin, S. 1994. Die Inschriften von Arykanda. Inschriften griechischer Städte aus Kleinasien 48. Bonn: Dr. Rudolf Habelt.

Şahin, S., and M. Adak. eds. 2007. Stadiasmus Patarensis. Itinera Romana Provinciae Lyciae. Monographien zu Gephyra I. Istanbul: Ege Yayınları. 
Şahin, S. 2009. "Kragos Oros, Titanis Petra und der Apollontempel von Patara. Lokalisierungsversuche in der historischen Geographie Lykiens." In Die Landschaft und die Religion. Stuttgarter Kolloquium zur Historischen Geographie des Altertums 9, 2005. Geographica Historica 26, edited by E. Olshausen and V. Sauer, 337-52. Stuttgart: Franz Steiner Verlag.

Şahin, S. 2012. "Kragos Oros, Titanis Petra ve Patara Apollon Tapınağı, Lykia'nın Tarihi Coğrafyası'na İlişkin Bir Lokalizasyon Denemesi.” In Eskiçağ Yazılar 3: 1-28, translated by N.E. Akyürek Şahin, edited by A.V. Çelgin and N.E. Akyürek. Istanbul: Arkeoloji ve Sanat Yayınları.

Talloen, P. 2006. "Pious Neighbours: Pisidian Religious Ties with Lycia: The Case of the Rider Deities." In The IIIrd Symposium on Lycia. Symposium Proceedings. Antalya, 07-10 November 2005. 2 vols., edited by K. Dörtlük, B. Varkıvanç, T. Kahya, J. des Courtils, M. Doğan Alparslan, and R. Boyraz, 747-59. Istanbul: AKMED.

Talloen, P. 2015. Cult in Pisidia. Religious Practice in Southwestern Asia Minor from Alexander the Great to the Rise of Christianity. A Study based on the Archaeological Research at Sagalassos. Studies in Eastern Mediterranean Archaeology 10. Turnhout: Brepols Publishers.

TAM II.2 Kalinka, E. 1930. Titvli Asia Minoris. Vol. 2, Fas. 2, Regio quae ad Xanthum flumen pertinat praetor Xanthum Oppidvm. Vienna: Akademie der Wissenschaften.

TAM II.3 Kalinka, E. 1944. Titvli Asia Minoris. Vol. 2, Fas. 3, Regiones Montanae, A Valle Xanthi Flvminis ad Oram Orientalem. Vienna: Akademie der Wissenschaften.

Tek, A.T. 2001. "Arykanda Kazılarında Bulunan Bir Myra Sikkesi." Günışı̆̆ında Anadolu, Cevdet Bayburtluoğlu İçin Yazılar / Essays in Honour of Cevdet Bayburtluoğlu, edited by C. Özgünel, O. Bingöl, V. İdil, S. Doruk, K. Görkay, and M. Kadıŏlu, 238-43. Istanbul: Homer Kitabevi.

Tek, A.T. 2002. "Arykanda Kazılarında Bulunan Antik Sikkeler Üzerinde Yeni İncelemeler: 1971-2000 Sezonları." Ph.D. diss., Ankara University.

Tek, A.T. 2006. "Hellenistik ve Erken Roma İmparatorluk Dönemlerinde Likya'da Basilan Otonom Şehir Sikkeleri." In The IIIrd Symposium on Lycia. Symposium Proceedings. Antalya, 07-10 November 2005. 2 vols., edited by K. Dörtlük, B. Varkıvanç, T. Kahya, J. des Courtils, M. Doğan Alparslan, and R. Boyraz, 769-87. Istanbul: AKMED.

Tek, A.T. 2020. "Antik ve Orta Çağ Kaynaklarında, Yazıtlarda ve Sikke Basımları ile Podalia." Olba 28:477-507.

Thomsen, A. 1995. "Suburbane Heiligtümer bei Kyaneai: Eine Quellfassung bei Kyaneai - das Orakelheiligtum des Apollon Thyrxeus?" In Lykische Studien 2. Forschungen auf dem Gebiet der Polis Kyaneai in Zentrallykien. Bericht über die Kampagne 1991. Asia Minor Studien 18, edited by F. Kolb, 43-48. Bonn: Dr. Rudolf Habelt.

Tiryaki, S.G. 2004. "Likya'da Kaynak Kültü." Master's thesis, Akdeniz University.

Tiryaki, S.G. 2006. "A Preliminary Evaluation of the Spring Cult and Related Structures in Lycia." Adalya 9:33-52.

Tiryaki, G. 2018. "The Sanctuary with the Relief of the 'Twelve Gods' in the Elmalı Highlands: On the Iconography of 'Leto, Her Children, and the Nymphs' in Ancient Southwest Anatolia." Adalya 21:135-50.

Tüner Önen, N. 2015. "Yeni Buluntular Işı̆̆ında Phaselis Epigrafi Çalışmaları." Phaselis 1:19-38.

von Aulock, H. 1974. Die Münzprägung des Gordian III und der Tranquilliana in Lykien. IstMitt Suppl. 11. Tübingen: Verlag Ernst Wasmuth.

von Aulock, H. 1977. Münzen und Städte Pisidiens. Vol. 1. IstMitt Suppl. 19. Tübingen: Verlag Ernst Wasmuth.

von Aulock, H. 1979. Münzen und Städte Pisidiens. Vol. 2. IstMitt Suppl. 22. Tübingen: Verlag Ernst Wasmuth. 
Weinreich, O. 1927. "Sozon." In RE III A-1, edited by G. Wissowa, W. Kroll, and K. Mittelhaus, $1248-256$. Stuttgart: J.B. Metzlersche Verlagsbuchhandlung

Wörrle, M. 1996. "Ein Weihaltar aus Kilepe/Yeşilköy.” In Fremde Zeiten, Festschrift für Jürgen Borchbardt zum sechzigsten Geburstag am 25. Februar 1996 dargebracht von Kollegen, Schülern und Freunden. 2 vols., edited by F. Blakolmer and F. Krinzinger et al., 153-60. Vienna: Phoibos Verlag.

Wurzer, J. 2015. "Griechische Quellheiligtümer in Kleinasien.” Master's thesis, University of Vienna.

Ziegler, R. 1999. "Das 'Koinoboulion eleutheron' in Anazarbos und Tarsos im frühen 3. Jh. n. Chr. Zu einer neuen anazarbischen Münze aus der Zeit des Elagabal.” NZ 106:95-98.

Zimmermann, M. 1992. Untersuchungen zur historischen Landeskunde Zentrallykiens. Antiquitas Reihe 1, Abhandlungen zur alten Geschichte 42. Bonn: Verlag Dr. Rudolf Habelt.

Zinko, M. 2002. "Laryngalvertretungen im Lykischen." Historische Sprachforschung 115.2:218-38.

Auction Firms Mentioned in the Text:

Auctiones A.G.

Leu=Bank Leu Ltd., Zurich

$\mathrm{CNG}=$ Classical Numismatic Group, Inc.

Künker=Fritz Rudolf Künker GmbH \& Co. KG

GM=Gorny \& Mosch Giessener Münzhandlung GmbH.

MM=Münzen \& Medaillen $\mathrm{GmbH}$

Naville $=$ Naville Numismatics

Naumann=Numismatik Naumann

Paul-Francis Jacquer

Roma Numismatics=Roma Numismatics Ltd.

Savoca $=$ Savoca Numismatic

Makale Geliş / Received : 31.12.2019

Makale Kabul / Accepted : 02.03.2020 

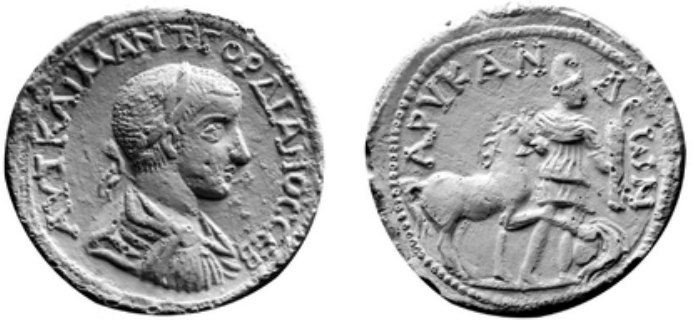

FIG. 1 Arykanda Cat. no. 1.
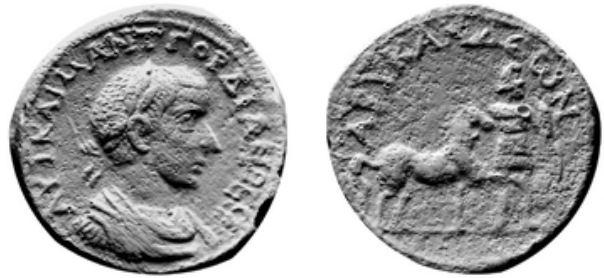

FIG. 3 Arykanda Cat. no. 3.
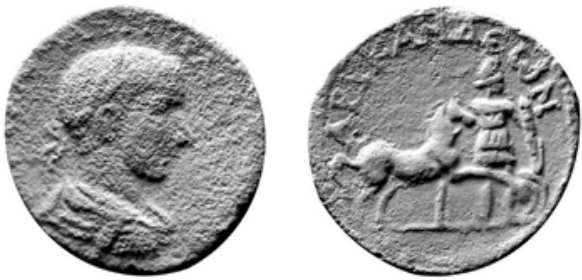

FIG. 5 Arykanda Cat. no. 5.
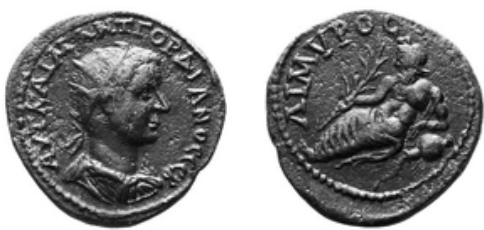

FIG. $7 \mathrm{AE}, 9.95 \mathrm{~g}, 24 \mathrm{~mm}$;

Limyra, Gordian III, reverse with River God Limyros (Savoca EA 16, 389)

(25.06.2017).
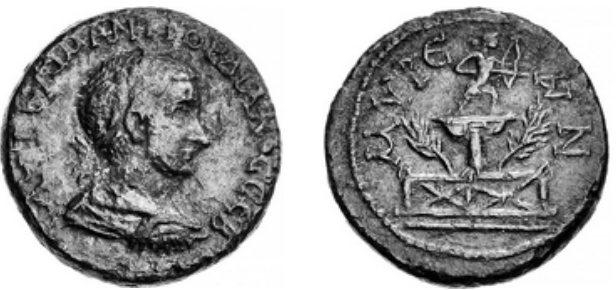

FIG. 9 AE, 19.24g, 31mm, 12h, Myra, Gordian III, reverse with a statue of Apollo Propylaeus drawing his bow, on a column with elaborate capital, flanked by two laurel trees in a space enclosed by a fence (CNG 88, 915) (14.09.2011).
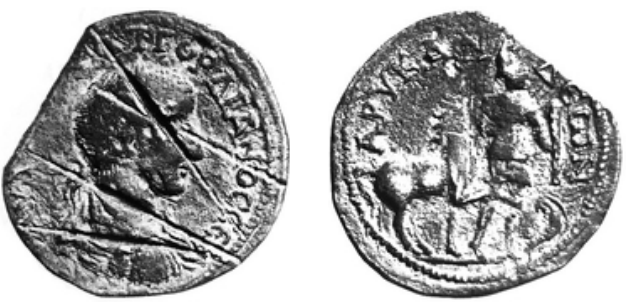

FIG. 2 Arykanda Cat. no. 2.
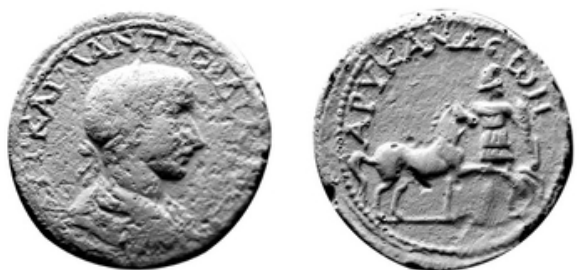

FIG. 4 Arykanda Cat. no. 4.
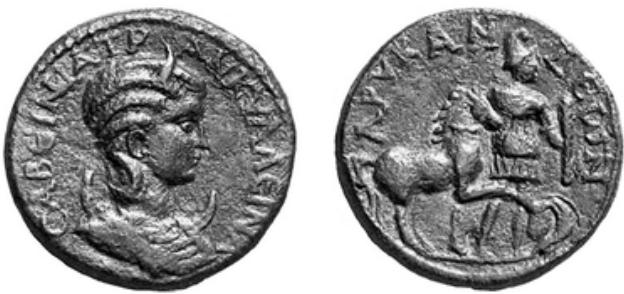

FIG. 6 Arykanda Cat. no. 6.
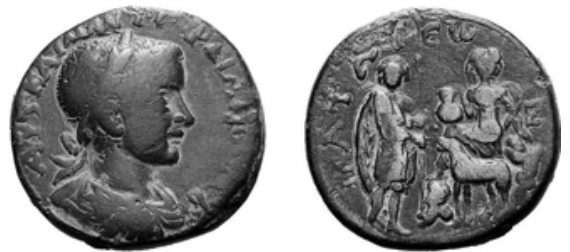

FIG. 8 AE, 17.12g, 27mm; 12h; Patara, Gordian III, reverse with, on right, a Nymph sitting on rocks supporting an urn on her knee, with a goat (or lamb?) and, on left, Dionysos holding his Thyrsos (Roma Numismatics, e-sale 60, 556) (01.08.2019).
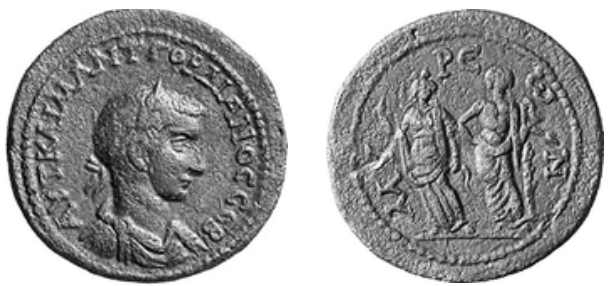

FIG. 10 AE, 22.61g; Myra, Gordian III, reverse with, on right, a standing semi-nude male figure (Apollo or Asklepios?) leaning to a tree trunk with snake coiled around it and, on left, a standing fully-dressed female figure (Nymph or Hygieia?) (GM 147, 1847) (07.03.2006). 

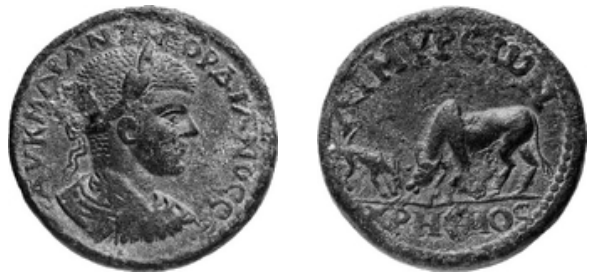

FIG. 11 AE, 20.04g, 29mm, 12; Limyra, Gordian III, reverse with gazelle (or goat?) and zebu drinking water from oracular source. Boston, Museum of Fine Arts, Inv. 1972.859 (Photo: https://www.mfa.org/).
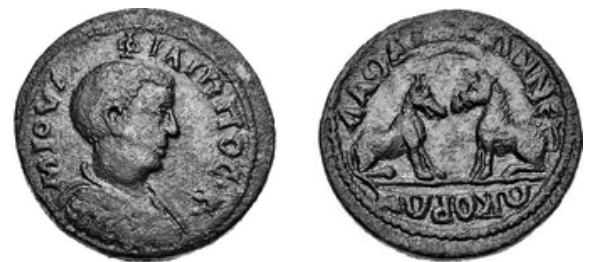

FIG. 13 AE, 8.20g, 27mm, 6h, Laodikeia (Phrygia), Philip II as Caesar, reverse with two facing animals symbolizing the rivers Lykos (wolf) and Kapros (boar) (CNG 87, 850) (18.05.2011).
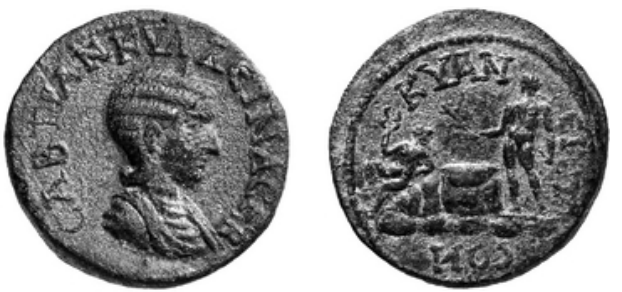

FIG. 15 AE, 23.74g; Kyaneai, Tranquillina, reverse with, on left, Hermes holding Kerykeion, reclining on rocks, and, on right, Apollo Thyrkseus, holding a branch over an altar at centre (GM 199, 606) (10.10.2011).

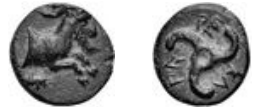

FIG. $12 \mathrm{AE}, 0.96 \mathrm{~g}, 11 \mathrm{~mm}$, Dynast Perikle (c. 380-360 BC). Obv. forepart of goat right. Rev. Triskeles with Perikle's name in Lykian (Roma Numismatics, E-sale 39, 289) (26.08.2017).

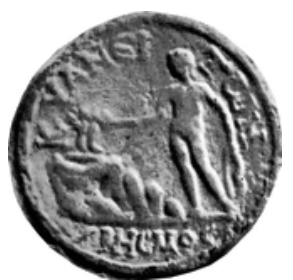

FIG. 14 AE, 18.29g; Kyaneai, Gordian III, reverse with Apollo Thyrkseus, holding a bow in his left hand and a branch (or laurel crown over a coiled snake?) with ribbons in his right which he seems to place on the rocks at left (von Aulock 1974, no. 92, pl. 6).
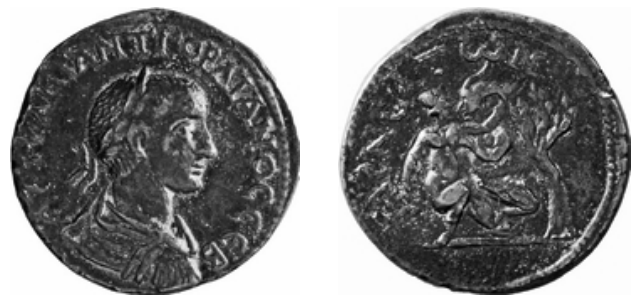

FIG. 16 AE, 18.74g, Arneai, Gordian III, reverse with Nymph and Pan. British Museum Inv. 1978.1021.3 (Photo: A.T. Tek). 


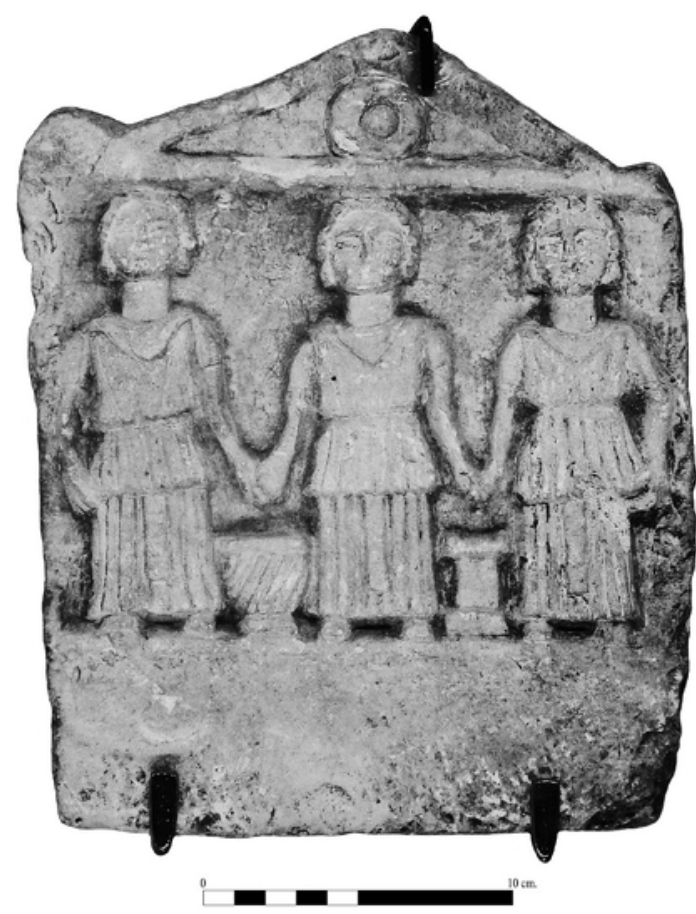

FIG. 17 Limestone stele from Arykanda excavated in 1997 and now in the Antalya Museum, showing a triad of Nymphs (Photo: H. Sancaktar).

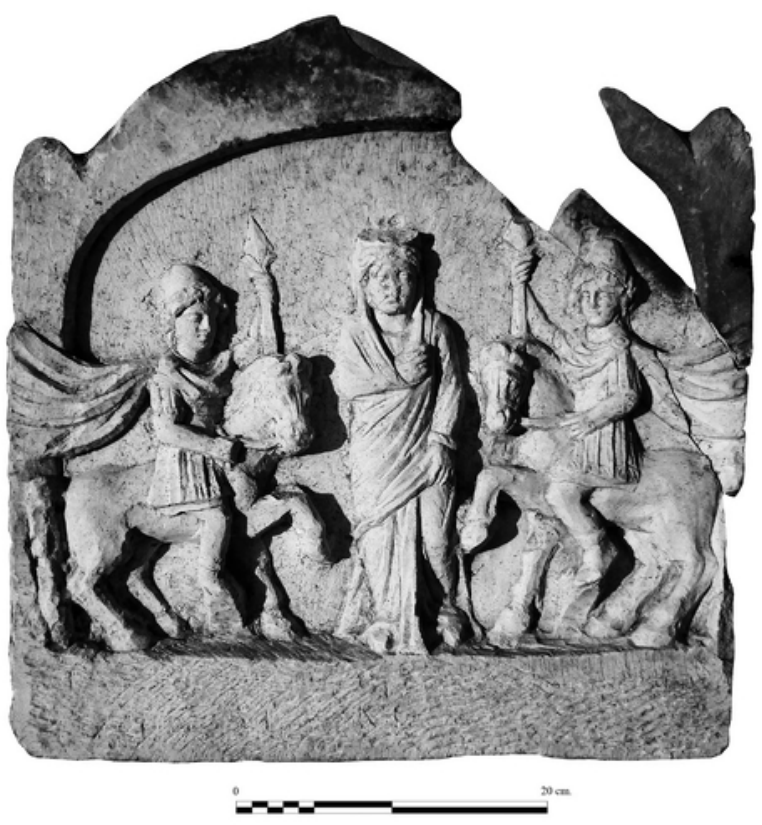

FIG. 20 Limestone stele from Arykanda excavated in 2012 and now in the Antalya Museum, showing the triad of Dioskouroi with a female deity (Photo: H. Sancaktar).
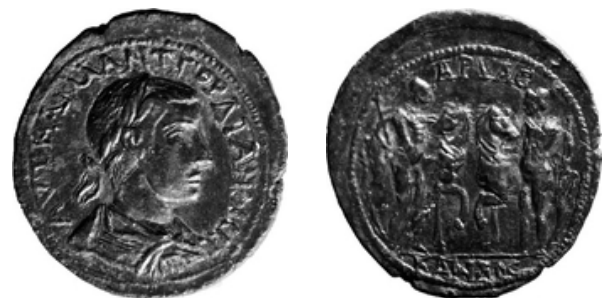

FIG. 18 AE, 37.15g, 6h, Arykanda, Gordian III, reverse with Aryas and Kandos, the eponym founders of Arykanda, named above and below figures with attributes of the Dioskouroi. British Museum Inv. 1991,0619.1 (Photo: A.T. Tek).
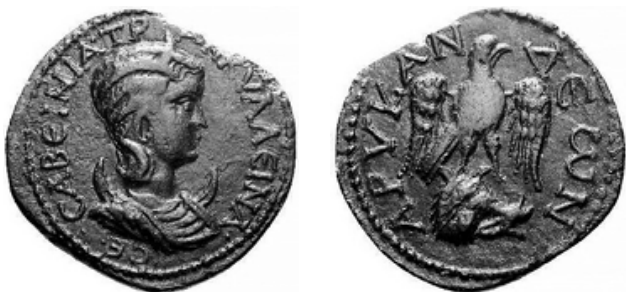

FIG. 19 AE, 18.25g, Arykanda, Tranquillina, reverse with scene of an eagle sitting on top of a wild boar's head, possibly referring to the oracle on the foundation of Arykanda (Auctiones A.G. 29, 361) (12.06.2003).

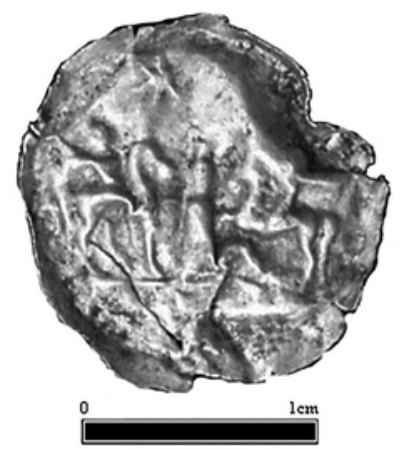

FIG. 21 AV medallion (?) from Arykanda excavated in 1992 and now in the Antalya Museum, showing the Dioskouroi flanking a female deity (Photo: H. Sancaktar).
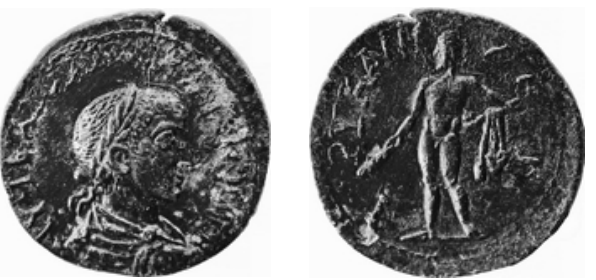

FIG. 22 AE, 15.55g, 30 mm; 12h; Arykanda, Gordian III, reverse with Herakles. Excavated on the Arykanda Acropolis in 2018 and now in the Antalya Museum (Photo: H. Sancaktar). 


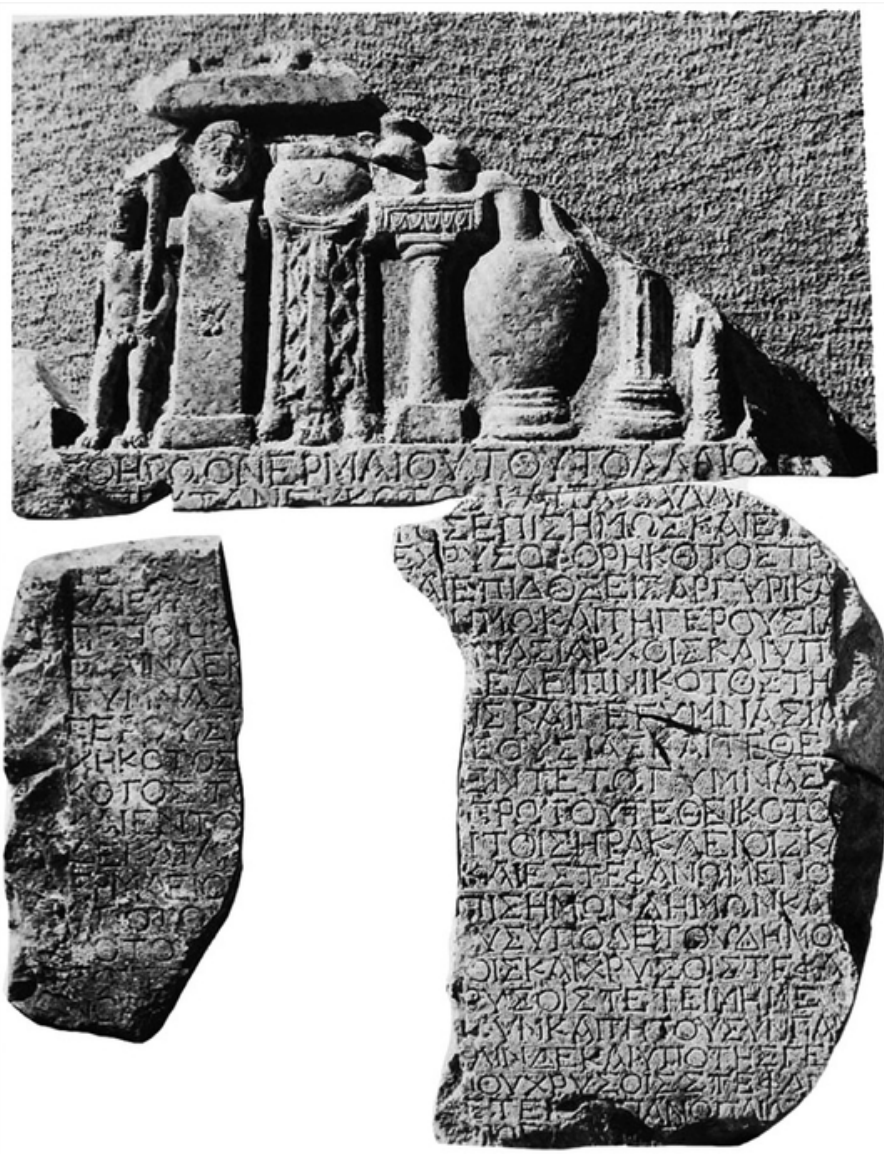

FIG. 23 Limestone inscription with relief from Arykanda, Heroon of Hermaios excavated in 1984, showing Herakles on the left with other Agon related items

(Şahin 1994, no. 162, pl. 29).

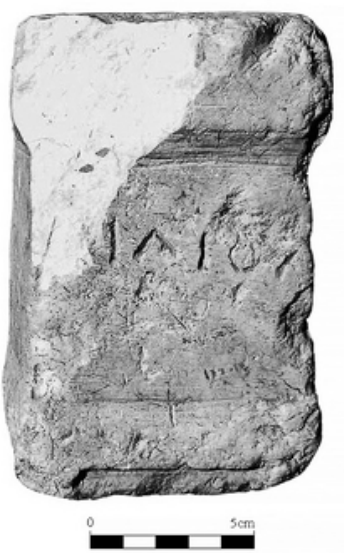

FIG. 28

Limestone altar excavated at the Temple of Helios in 1990, with radiate and draped bust of Helios facing, now in the Antalya Museum (Sancaktar 2019, Cat. no. AS1).

FIG. 27

imestone altar excavated at the Temple of Helios in 1990, inscribed H $\Lambda$ IOY (of Helios) and now in the Antalya Museum (Sancaktar 2019, Cat. no. Y6).
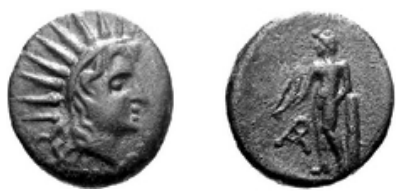

FIG. $24 \mathrm{AE}, 4.73 \mathrm{~g}$, Arykanda, 2nd-1st century BC (Before 81 BC). Obv. radiate bust of Helios right. Rev. Apollo Daphneus, standing holding bow and leaning on pillar (Auctiones A.G. 29, 360) (12.06.2003).
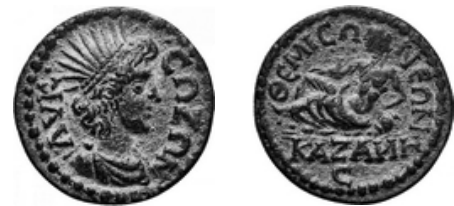

FIG. 25 AE, 5.89g, 22mm;

Themisonium (Phrygia), Late 2nd-mid 3 rd century AD. Obv. radiate and draped bust of Sozon named $C \Omega Z \Omega N$ in legend (Naumann, 44, 723) (07.08.2016).
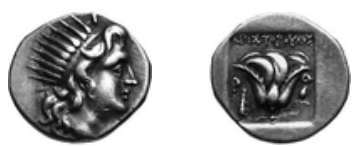

FIG. 26 AR, 3.00g, 15mm; 12h; Rhodes, c. 188-170 BC. Obv. radiate head of Helios (CNG EA 266, 163) (19.10.2011).

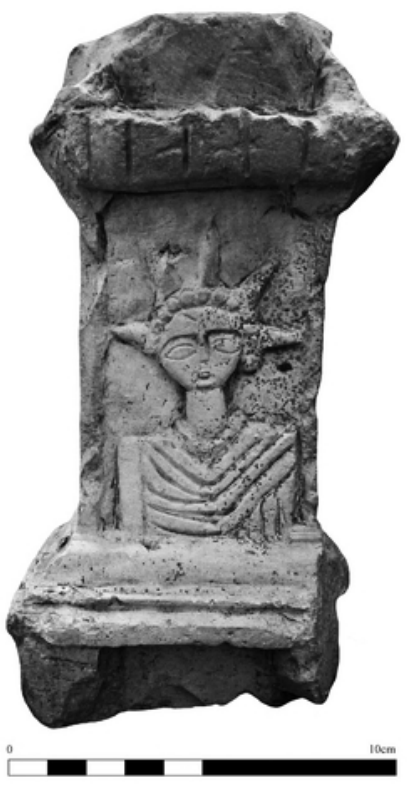




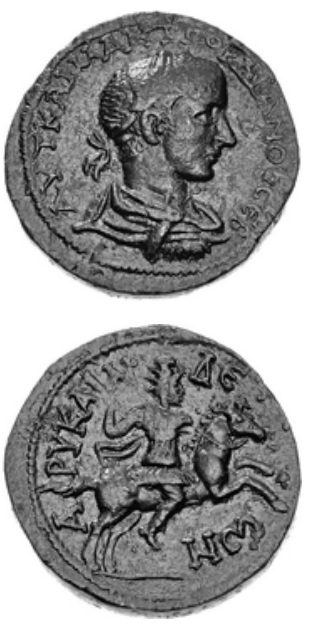

FIG. $29 \mathrm{AE}, 23.51 \mathrm{~g}$, 32mm, 12h; Arykanda, Gordian III, reverse with syncretic Helios riding (CNG 93, 824) (22.05.2013).
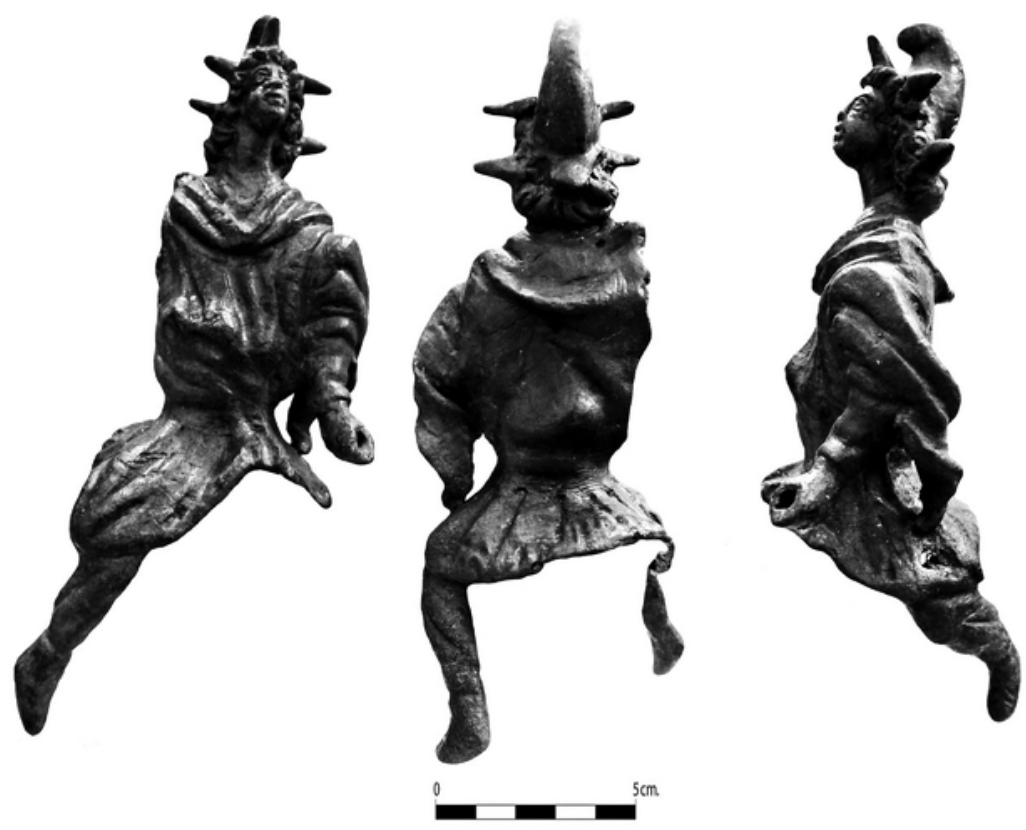

FIG. 30 Bronze figurine from Arykanda depicting syncretic Helios riding a horse (now missing), with right hand (now missing) holding club raised to strike, and with left holding the reins. Excavated at the Temple of Helios in 2002 and now in the Antalya Museum (Sancaktar 2019, Cat. no. F1).
FIG. 31

Fragmentary limestone relief with inscription from Arykanda, excavated from the Temple of Helios in 2002. The inscription

says "dedicated by $X$, to (the gods $X$ or more) Helios and Selene". Present fragment shows three figures, Helios in the middle named under dressed in rider attire and holding the bridle of his horse, Selene, also named under, standing facing with crescent on her shoulders and a bull's head beside her feet. Now in Elmalı Museum (Sancaktar 2019, Cat. no. Y16).

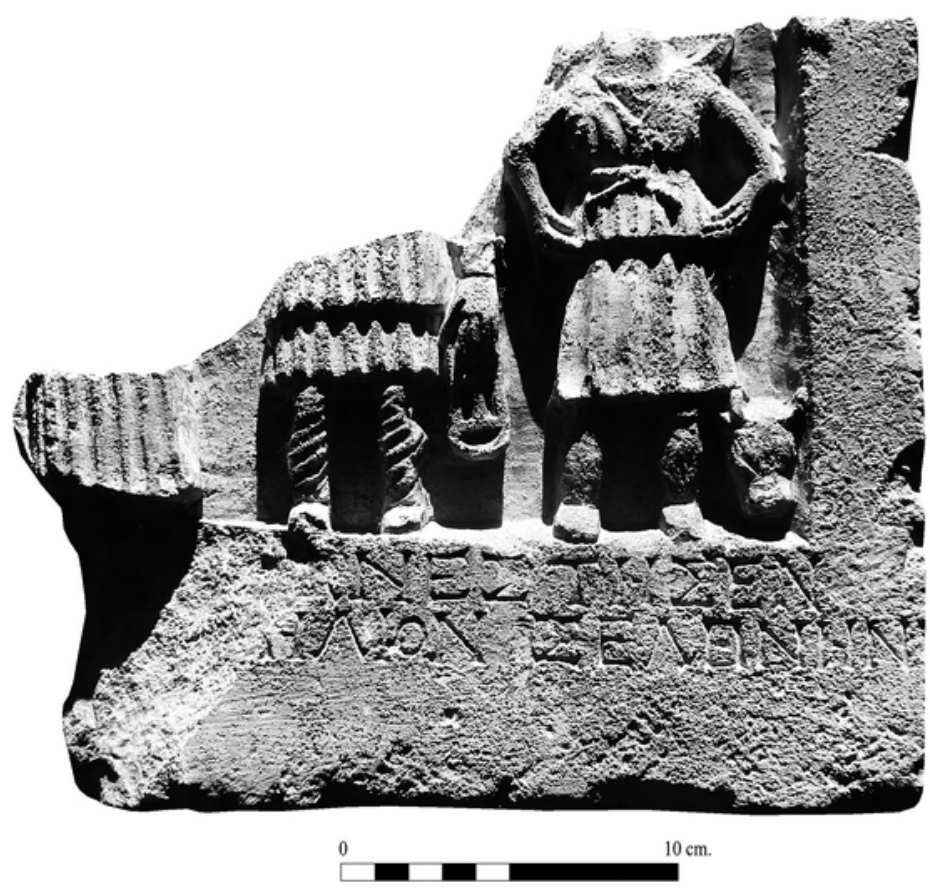



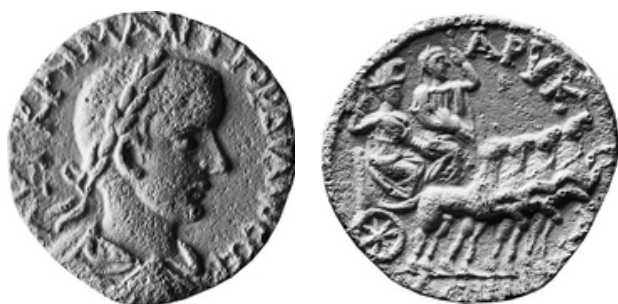

FIG. 32 AE, 17.71g, 28/29mm, 6h, Arykanda, Gordian III, reverse with Helios wearing rayed Thracian helmet, holding club in raised right hand and reins in left, seated on left; and Zeus, holding thunderbolt in right hand and scepter in left, seated on right in a quadriga going right. Excavated from Arykanda in 1989 and now in the Antalya Museum (Photo: A.T. Tek).
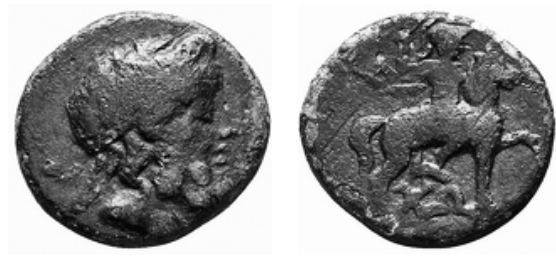

FIG. 34 AE, 3.75g, 15mm;

Khoma, 1st century BC (Before 46 BC).

Obv. laurate head of Zeus right.

Rev. Kakasbos wearing crested Corinthian helmet, chlamys and cuirass, riding his horse right with right hand raised holding club. Between the horse's legs X $\Omega$ (Savoca Blue 10, 710) (29.09.2018).
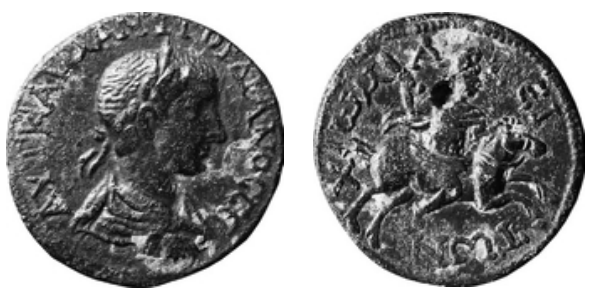

FIG. 35 AE, 15.35g, 29/31mm, 12h;

Khoma, Gordian III, reverse with Kakasbos wearing Thracian helmet, chlamys and cuirass, riding his horse right with right hand raised holding club. Excavated from Arykanda in 1990 and now in the Antalya Museum, Inv. 7946 (Tek 2002, no. 974)

(Photo: A.T. Tek).

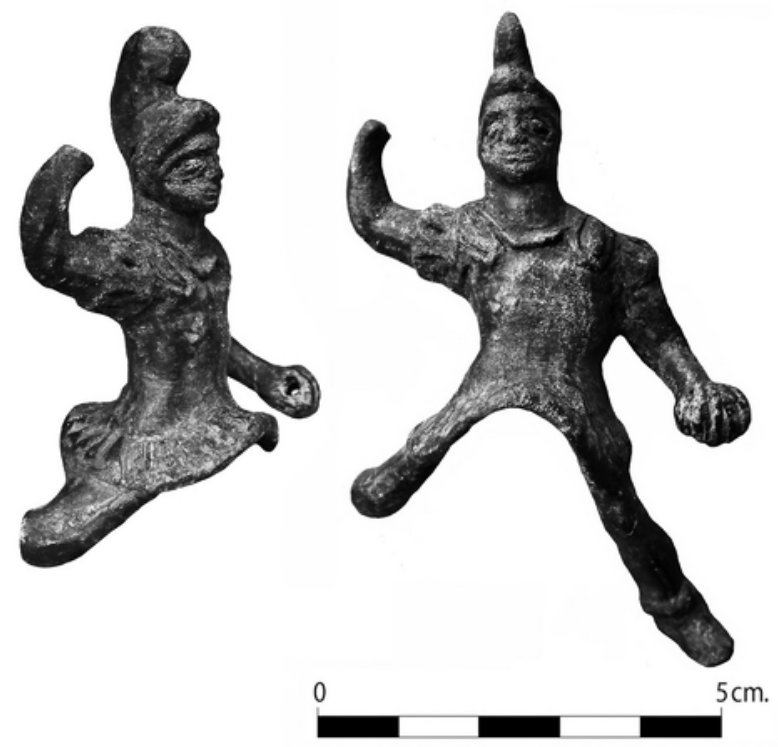

FIG. 33 Bronze figure excavated in Arykanda, depicting Kakasbos, riding horse (now missing), in right hand holding club (now missing) raised to strike, and in left holding the reins (Photo: H. Sancaktar).

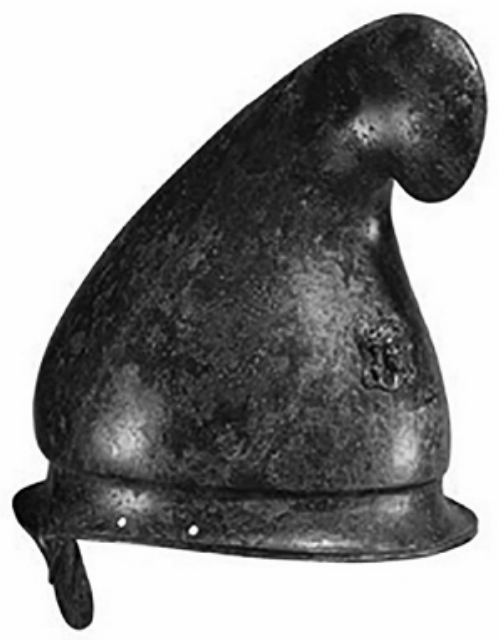

FIG. 36 Thracian-type helmet excavated from Sashova Tumulus at Kazanlak in Thrace, Bulgaria, National Museum, Sofia. 


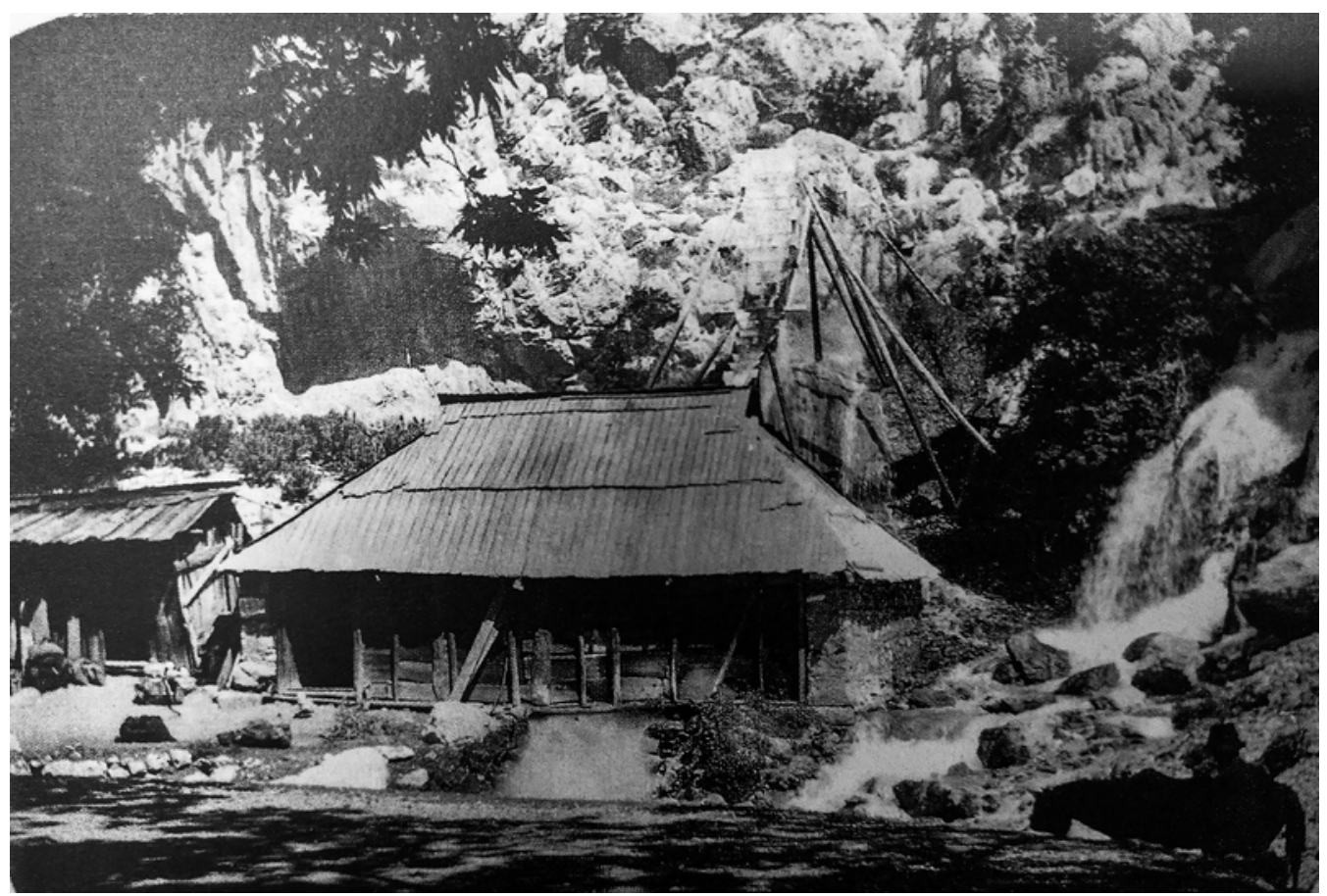

FIG. 37 Water mill and road at Suyun Gözü as photographed in 1892. The water source and the first stele set on the rocks are visible on the right (E. Krickl, 1892).

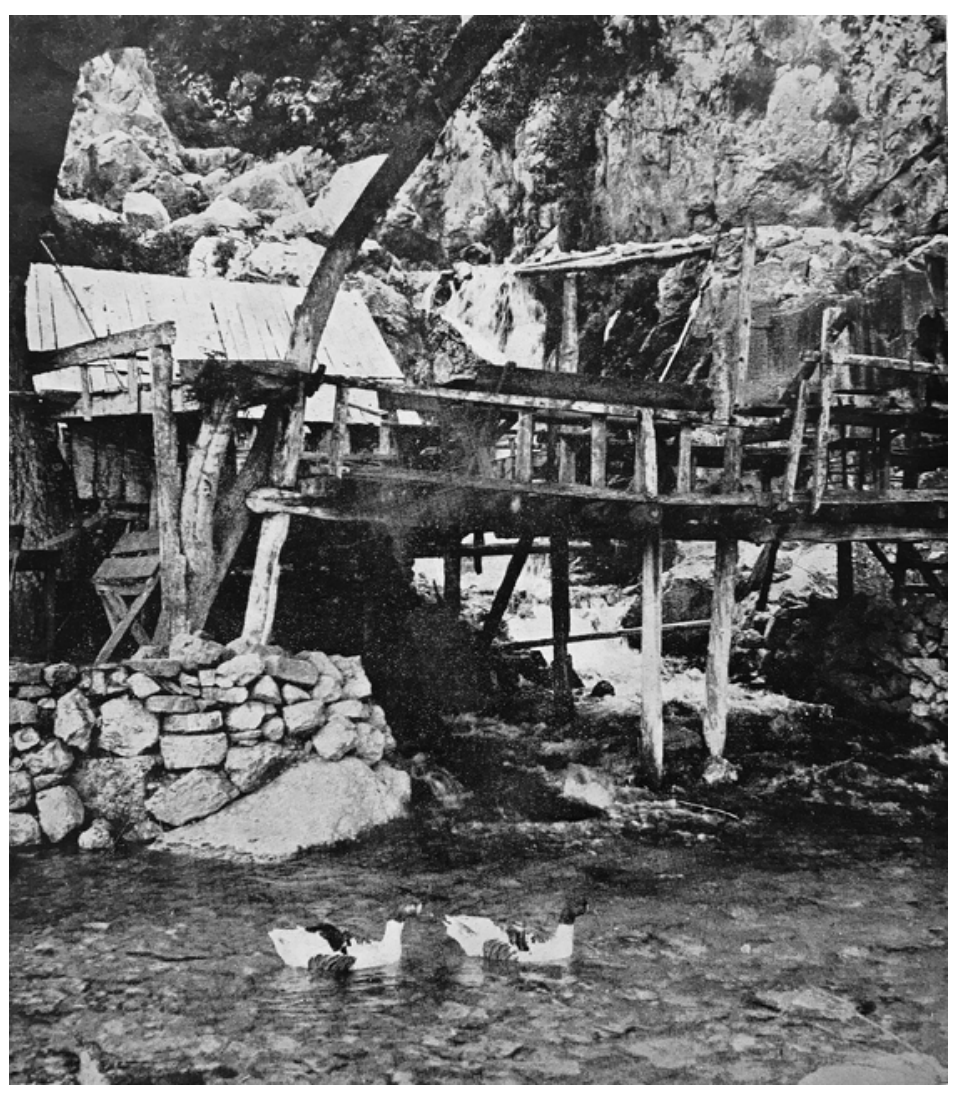

FIG. 38

Water mill and coffee house at Suyun Gözü as photographed in 1950 before the area was filled in for the new road. Rock with stele setting is visible on the right towards top (Onat 1964). 


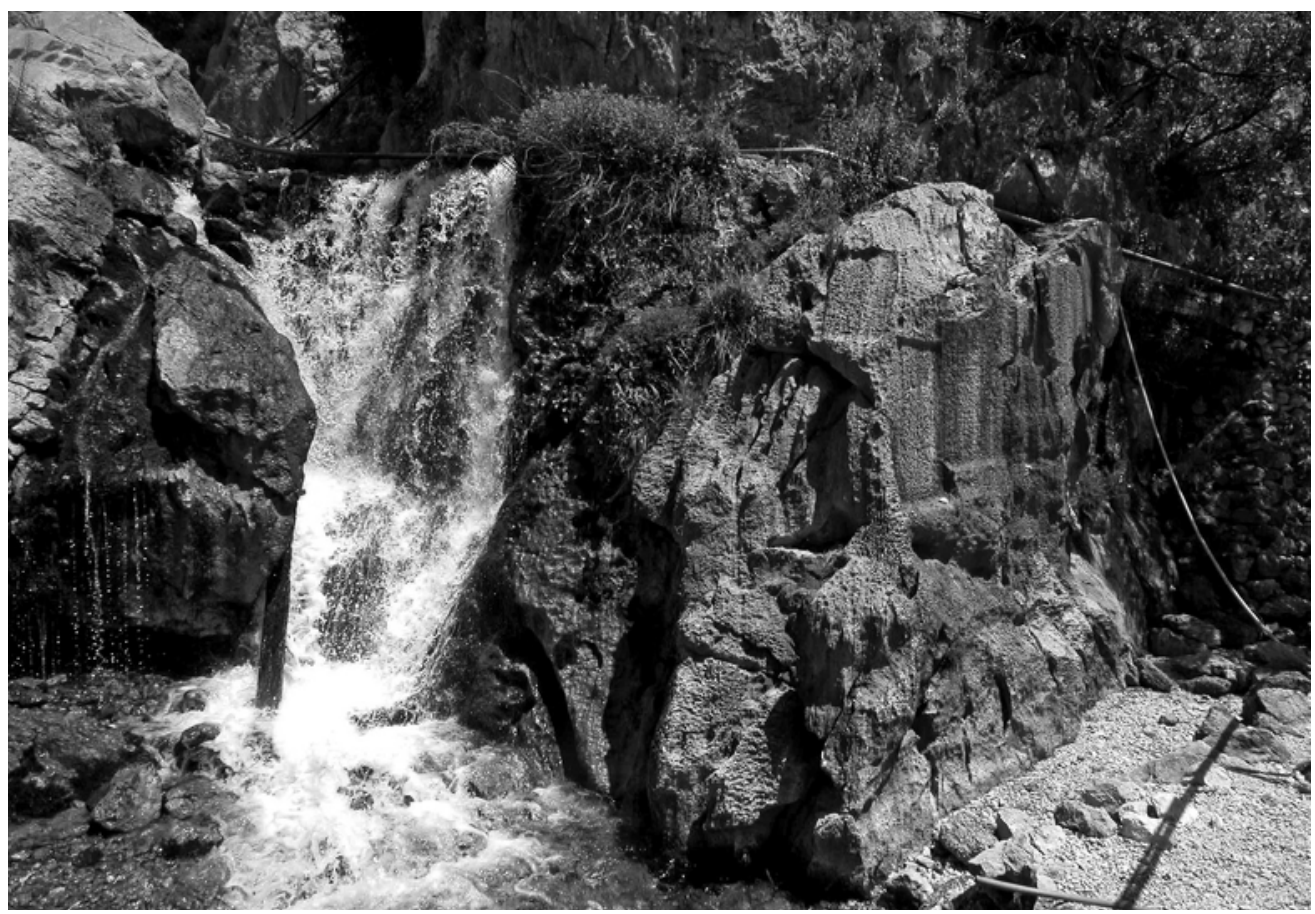

FIG. 39 Water source and rock sanctuary at Suyun Gözü as photographed in 2006 (Photo: A.T. Tek).

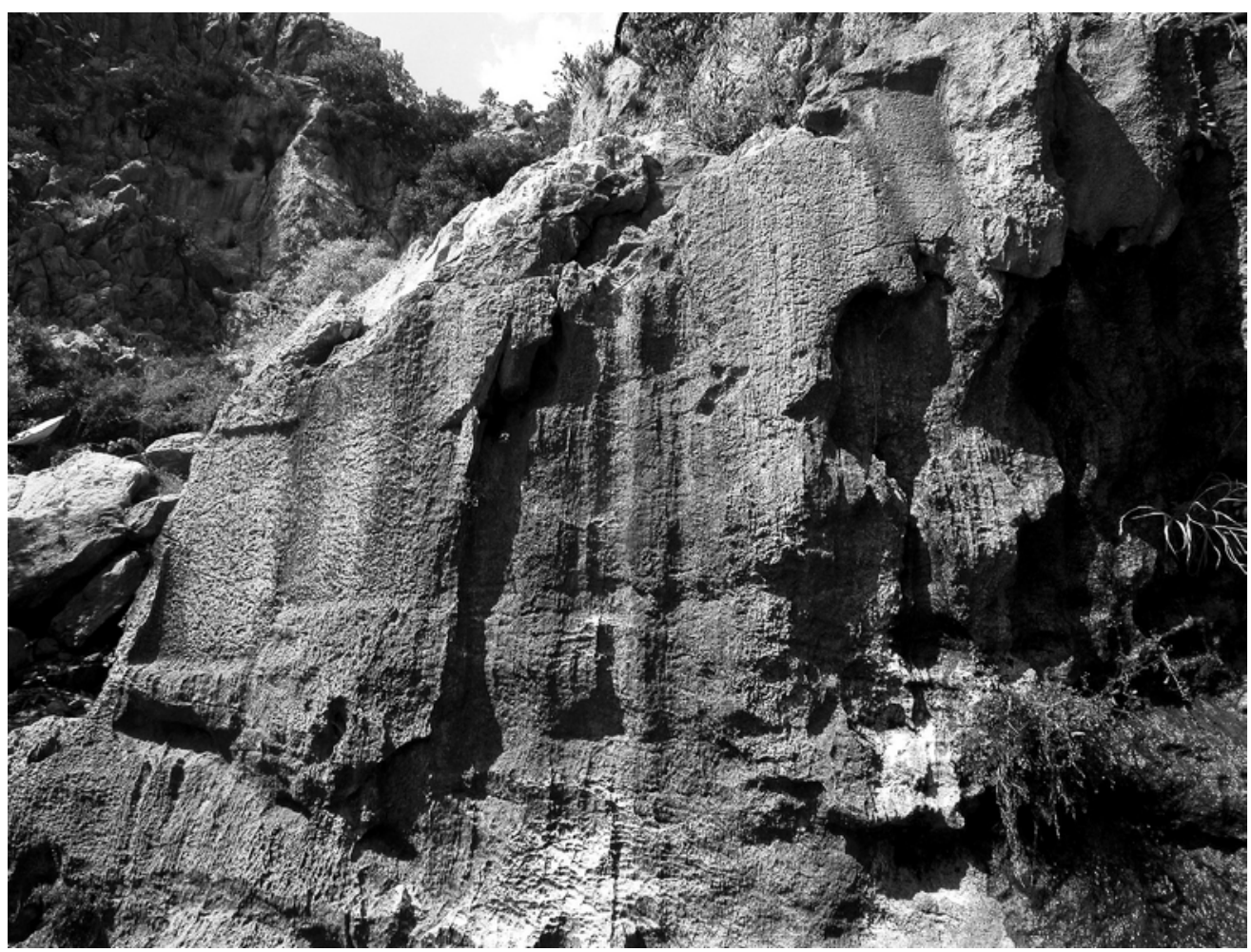

FIG. 40 Stele slots on the face of the rock sanctuary at Suyun Gözü in 2006 (Photo: A.T. Tek, 2006). 
